\title{
SIZE AND BOOK TO MARKET EFFECTS: FURTHER EVIDENCE FROM THE FRENCH CASE
}

\begin{abstract}
The objective of this paper is to study the market, $S M B, H M L$ and the leverage factors in explaining cross-sectional returns. We provide the first empirical analysis of Ferguson and Shockley (2003) theoretical framework on the French stock market. Book to market and size, variables which are correlated with leverage, will appear to explain returns. Our main result is that the leverage factor doesn't subsume the $S M B$ and $H M L$ factors. In cross-sectional regressions, only the size premium is statistically significant and help explaining returns. In timeseries regressions, the three factors ( $S M B, H M L$ and leverage), with the market portfolio, do a good job. This result suggests that the leverage portfolio has an additional improvement of the model.
\end{abstract}

Key words and phrases. Asset Pricing, Anomalies, Risk factors and The Fama and French Model. 


\section{INTRODUCTION}

The first and the most widely used model of asset pricing is the Capital Asset Pricing Model CAPM ( Sharpe (1964), Lintner (1965), Mossin (1966) and Black (1972)). Because of its simplicity, the beta $(\beta)$ revolution has had significant impact on the academic and non-academic financial community. The model assumes that investors respect the Markowitz mean-variance criterion in choosing their portfolios. Its well-known prediction is that the expected excess return on an asset equals the $\beta$ of the asset times the expected excess return on the market portfolio, where the $\beta$ is the covariance of the asset's returns with the returns on the market portfolio divided by the variance of the market returns. Roll (1977) argued that the model is not testable because the tests involve a joint hypothesis on the model and the choice of the market portfolio. This problem of joint hypothesis tests was mentioned by other authors ( Ball (1978)).

On the theoretical side, many factor pricing models attempted to explain the cross-section of average asset returns [The Inter-temporal Capital Asset Pricing Model ( Merton (1973)), The Arbitrage Pricing Model ( Ross (1976)) and the intertemporal capital asset pricing model based on consumption ( Rubinstein (1976), Lucas (1978), Breeden (1979) among others)]. However, as Cochrane (2001) has mentioned, all factor models are consumption-based models.

Nevertheless, many patterns emerge from empirical studies which are not explained by the CAPM. Stocks with high earnings to price ratio have, on average, higher returns than stocks with low ratio (Nicholson (1960) and Nicholson (1968), Basu (1977)). Litzenberger and K. (1979) pointed out a linear positive relation 


\section{Size And Book to Market Effects: Further Evidence}

between the dividend yield and the stock returns. Small capitalizations have higher expected returns than big ones ( Banz (1981), Reinganum (1981), Basu (1983)). Schwert $(1983)^{1}$ offered a summary of empirical studies on the size effect. There is a positive relation between the level of debt and stock returns (Bhandari (1988)) and the book to market ratio is considered as an explanatory variable in stock returns ( Stattman (1980), Fama and French (1991), Fama (1991), Chan et al. (1991) and Fama and French (1992)). However, there exist many empirical studies that give contradictory conclusions about these anomalies. Grauer (1999) show that neither the least square method nor the generalized square method can help to know if the mean-variance model is true or false a posteriori ${ }^{2}$.

In our study, we test two hypothesis on the size and the book to market effects on The French Stock Market over July 1976 to June 2001 period.

The first hypothesis is the three factor model of Fama and French (1993). The two authors argue that $H M L$ and $S M B$ portfolios, with the market portfolio, do a good job in explaining cross-sectional returns. Their model summarizes earlier empirical observations and results. However, it is much debated: To be a compensation for risk in a multi-factor version of Merton's (1973) Inter-temporal Capital Asset Pricing Model (ICAPM) or Ross's (1976) Arbitrage Pricing Theory (APT), factors must be related to state variables which justify a risk premium.

The second hypothesis is the proposition of Ferguson and Shockley (2003). The two authors show that the CAPM doesn't work because, in empirical studies, we use an equity-only proxy for the true market portfolio and we ignore the debt claims. 
Book to market and size, variables which are correlated with leverage, will appear to explain returns.

Our primary contribution is to provide the first empirical analysis of Ferguson and Shockley (2003) theoretical framework on the French stock market. The aim is to study the market, $S M B, H M L$ and the leverage factors in explaining crosssectional returns. The main result is that the leverage factor doesn't subsume the $S M B$ and $H M L$ factors. In cross-sectional regressions, only the size premium is statistically significant and help explaining returns. In time-series regressions, the three factors ( $S M B, H M L$ and leverage), with the market portfolio, do a good job. This result suggests that the theoretical framework of Ferguson and Shockley (2003) is worth interesting. The leverage portfolio has an additional improvement of the model. Nevertheless, it doesn't explain the $S M B$ and $H M L$ factors in the French case.

In the next section, we give a brief summary of the theoretical framework of our study. Methodology used and database considered are discussed in the second part of the paper. In sections three and four, we summarize results and then we conclude.

\section{Theoretical Framework}

2.1. The Three Factor Model. Summarizing earlier empirical observations and results, Fama and French (1993) argue that size and book to market ratio are 


\section{Size And Book to Market Effects: Further Evidence}

factors of risk that we must remunerate. The unconditional version ${ }^{3}$ of the model is expressed in the equation 2.1 .

$$
E\left(R_{i}\right)-R_{f}=\beta_{i}\left(E\left(R_{M}\right)-R_{f}\right)+s_{i} E(S M B)+h_{i} E(H M L)
$$

with $E\left(R_{i}\right)$ : expected stock return; $R_{f}$ : risk free rate; $E\left(R_{M}\right)$ : expected return of market portfolio; $E(S M B)$ (Small Minus Big): is the difference between the equalweight averages of the returns on the three small stock portfolios and the three big stock portfolios; $E(H M L)$ (High book to market Minus Low book to market): is the difference between the return on a portfolio of high book to market stocks and the return on a portfolio of low book to market stocks, sorted be neutral with respect to size; and $\beta_{i}, s_{i}, h_{i}$ : are factor loadings.

Indeed, on the basis of two criteria, size and book to market (BE/ME), Fama and French construct twenty five portfolios, from a sample of the stocks of the NYSE, AMEX and NASD over 366 months (From June 1963 to December 1993). Because monthly stock returns of stocks of small capitalization and high book to market ratio are, on average, higher than these of big capitalizations and low book to market ratio, the two authors propose the following regression 2.2:

$$
R_{i}-R_{f}=\alpha_{i}+\beta_{i}\left(R_{M}-R_{f}\right)+s_{i} S M B+h_{i} H M L+\epsilon_{i}
$$

The results show that the coefficient $\alpha_{i}$ is negative for portfolios located in the extreme quantiles of the stocks of small capitalizations and low ratio book to market and positive for portfolios located in the extreme quantiles of the stocks of big 
capitalizations and high book to market ratio. In addition to these results on the extremes, the coefficient $\alpha_{i}$ is not significantly different from zero; which makes it possible to affirm that the three factor model explains cross-section stock returns.

Financial literature focusing on explications of size and book to market effects is very large are rich. We limit the presentation here to the main propositions on this subject. ( Lakonishok et al. (1994) and MacKinlay (1995)) argue that the premium of the financial distress is irrational. First of all it can express an over-reaction of the investors. Second, stock returns of firms with distressed financial situation are low, not necessarily during periods of low growth rate of Gross National Product ${ }^{4}$ or of low returns of all stocks. Lastly, diversified portfolios of stocks with, as well high as low, ratio book to market; have the same variance of returns.

Other researchers documented other arguments ${ }^{5}$ which are inconsistent with the premium of the financial distress: (a) Survivor bias( Kothari et al. (1995)): But it should be noticed that even if the critic of the survivor biais is true, it is not necessarily in favor of the CAPM ( Kim (1997), Barber and Lyon (1997)). (b) Data-snooping( Black (1993b), Black (1993a), Lo and MacKinlay (1990)): An extrapolation of data can lead to false conclusions, so how we need the out-ofsample tests. Fama and French (1996b) and Fama and French (1996a) reject this biais $^{6}$. Moreover, the relation between stock returns and the book to market ratio was confirmed by: Davis (1994) on data over a long period; Chan et al. (1991) on Japanese data and Barber and Lyon (1997) on data on the financial institutions ${ }^{7}$, among others. (c) Bad market proxies: Indeed, according to this argument, the model of asset pricing to be retained is that of the CAPM and because we don't 


\section{Size And Book to Market Effects: Further Evidence}

know the market portfolio we have anomalies. This is why, the "real" $\beta$ s are not observed. This problem is called errors-in-variables ( Kim (1997)).

\subsection{Competing Explanations of Size and Book to Market Anomalies. Nev-}

ertheless, there are many attempts to give theoretical explanation for the three factor model. A competing model of the three factor model of Fama and French is the model of the characteristics of the firm of Daniel and Titman (1997). Indeed, Daniel and Titman give a different interpretation for the relation between book to market ratio and stock returns. They reject the assumption of "factor of risk" in favor of the model of "the characteristics of the firm": A low book to market ratio, which is one of the characteristics of the large firms, causes a low stock returns which does not, necessarily, correspond to a risk.

Daniel and Titman (1997) reject the factor model for the U.S. stocks. However, Davis et al. (2000) show that this interpretation is specific to the period of study and confirm the results of the three factor model. In the same way, Lewellen (1999) confirms the superiority of the model of Fama and French (1993) compared to the model of Daniel and Titman (1997) in explaining time-varying expected returns on the U.S. market. Daniel et al. (2000) replicate the Daniel and Titman tests on a Japanese sample and fail to reject the characteristic model ${ }^{8}$.

Berk et al. (1999) give a micro-economic model of the firm which integrate options of growth investments. The simulations of the model give consistent results with the conclusions of the three factor model. More recently, Ferguson and Shockley (2003) explain that the factor portfolios of Fama and French are correlated with a missing beta risk related to leverage. The empirical application of their model show 
that relative leverage and relative distress are powerful in explaining cross-sectional returns.

Indeed, Ferguson and Shockley (2003) propose a continuous-time economy in which the CAPM prices all real assets. Equity claims of firms are considered as European calls on the underlying real assets. The model determines explicitly the beta estimation errors that will arise because of the use of the inefficient equity-only proxy. We don't develop their theoretical analysis in detail here. Nevertheless, in this paper, we provide an empirical investigation of their theoretical proposition in the French case.

\section{Size and Book to Market Sorted Portfolios}

3.1. Database and methodology. We study monthly returns on stock portfolios for France. Portfolios use all French stocks with the relevant Datastream data. Only the stocks with available market and accounting data are used. The total number of stocks is $636^{9}$. We consider the period from July 1976 to June 2001 (300 months). As Fama and French(1993), we make two classifications.

A book to market classification: $30 \%$ of the stocks are grouped in the class of high ratio $\mathrm{B} / \mathrm{M}, 40 \%$ of the stocks in the class of medium ratio $\mathrm{B} / \mathrm{M}$ and $30 \%$ of the stocks in the class of low ratio B/M. We consider book to market ratio of December of the year $(t-1)$ for the formation of the portfolios for the period from July of year $(t)$ to June of year $(t+1)$. Book to market ratio is calculated as being the reverse of the variable Market Value To Book which appears in the database of Datastream ${ }^{10}$. Unlike Fama and French who used the breakpoints of the ranked values of book to market for NYSE stocks to group NYSE, Amex and NASDAQ stocks, we use the 


\section{Size And Book to Market Effects: Further Evidence}

breakpoints of the whole sample to make our classification. Like Fama and French, we do not use negative book to market firms.

We can ask about the significance of a book to market classification? Indeed, a simple understanding of a low book to market ratio is that the market value of the firm is high relative to its book value. This is the case of firms with high growth investment opportunities. Another possible explanation is the existence of intangible assets, like investments in research and development. We mention also the case of firms with low risk with can be expressed in a high market value. Nevertheless, the understanding of the book to market ratio must be made in a context of three dimensions: the life-cycle of the firm, the sector and the stock market.

A size classification: The stocks are grouped in two classes; the stocks of small capitalizations and these of big capitalizations. We consider the capitalization ${ }^{11}$ of June of year $(t)$ for the formation of portfolios for the period from July of year $(t)$ to June of year $(t+1)$. Unlike Fama and French who used the median NYSE size to split NYSE, Amex and NASDAQ stocks (that's why the two size groups contain disproportionate numbers of stocks), we use the median size of the whole sample to make our classification.

In financial literature, many authors ask about the variable to use in making the size classification. In empirical studies, it is usual to consider the market value. Nevertheless, this variable is subject of debate ${ }^{12}$. As we have mentioned earlier, in our study we consider the market value for the size classification. A firm is classified in small capitalisation for different raisons. We summarize all possible explanations in three categories. First, we have small firms because of their sector of activity. 
Second, firms in the beginning of their life-cycle can be classified, temporary, in small capitalizations. Finally, we have destressed firms.

The splits (three book to market groups and two size groups) are arbitrary. However Fama and French (1993) argued that there is no reason that tests are sensitive to this choice. Six portfolios (HS, HB, MS, MB, LS, and LB) are formed with the intersection of the two preceding classifications, made yearly and independently. The monthly returns of each portfolio corresponds to the value-weight monthly returns of the stocks assigned to the portfolio: $R_{p, t}=\sum_{i=1}^{n} \omega_{i, t} * R_{i, t}{ }^{13}$.

In our study, the risk free interest rate used is the monthly equivalent rate to: Short term interest rate for the period from July 1976 to January 1981, Money market, one month, rate from February 1981 to January 1987, PIBOR from February 1987 to December 1998 and EURIBOR from January 1999 to June 2001.

Table 1 shows that the portfolios in the smallest size quintile and the lowest book to market quintile and these in the biggest size quintile and the highest book to market quintile contain, on average, less stocks than other portfolios. Like table 1 in Fama and French (1993), in the smallest (biggest) size quintile, the number of stocks increases (decreases) from lower to higher book to market portfolios.

Two portfolios, $H M L$ and $S M B$, are formed from the six portfolios presented above. Indeed, the monthly stock returns of portfolio $H M L$ correspond to the difference between the average monthly stock returns of the two portfolios of high $\mathrm{B} / \mathrm{M}$ ratio (HS and $\mathrm{HB}$ ) and the average monthly stock returns of the two portfolios of low B/M ratio (LS and LB): $H M L=\{(H S+H B)-(L S+L B)\} / 2$. 


\section{Size And Book to Market Effects: Further Evidence}

As for the monthly stock returns of portfolio $S M B$, it corresponds to the difference between the average monthly stock returns of the three portfolios of small capitalization (HS, MS and LS) and the average monthly stock returns of the three portfolios of high capitalization (HB, MB and LB): $S M B=\{(H S+M S+L S)-$ $(H B+M B+L B)\} / 3$. The market portfolio is the value-weight returns of all the stocks (stocks are weighted by their market value).

Table 1 shows also average values of explanatory variables. These values give the average risk premiums for the common factors in returns. The average value of excess returns of market portfolio is $1.134 \%$ per month with $3.157 t$-statistic. This is large compared to Fama and French (1993) in the US-case (only 0.43\% with 1.76 standard errors from zero) and Molay (2001) in the French case (0.61\% with 1.36 standard errors from zero ${ }^{14}$. However, Fama and French (1998) documented an average annual value for the market portfolio in the French case about $11.26 \%(0.89 \%$ per month) and Heston et al. (1999) ${ }^{15}$ about $1.21 \%$ per month. The average $H M L$ return is only $0.597 \%$ per month with 1.758 standard errors from zero. The size factor $S M B$ produces an average premium of $0.742 \%$ per month and the $t$-statistic is 2.771 .

[Insert table 1 here]

Unlike Fama and French (1993), table 1 shows that $H M L$ portfolio returns have positive correlation with excess market and $S M B$ portfolio returns (0.079 and 0.164 respectively). $S M B$ and market portfolio have negative correlation ${ }^{16}$. The main observation is that we have low correlation between the three explanatory variables. 
3.2. Empirical Results: The Three Factor Model Regressions. In this subsection, we show only time-series regressions. For purpose of comparaison, the crosssectional regression results for the three factor model are presented in the following section. Explanatory variables; Market, $H M \operatorname{Land} S M B$; from the equation of the three factor model of Fama and French are defined earlier. For the dependent variable of our time-series regressions, we consider 16 stock portfolio returns. Indeed, we group, independently, stocks in four quintiles of size (from Small to Big) and book to market (from Low to High). We obtain 16 portfolios from the intersection of the two sorts. We regress monthly returns of these 16 portfolios on the three explanatory variables for the period from July 1976 to June 2001. The monthly returns of each portfolio corresponds to the value-weight monthly returns of the stocks assigned to the portfolio (see expression ??). Our time-series regressions are as follows:

$$
R_{i}-R_{f}=\alpha_{i}+\beta_{i}\left(R_{M}-R_{f}\right)+s_{i} S M B+h_{i} H M L+\epsilon_{i}
$$

[Insert table 2 here]

Table 2 summarizes some characteristics of the 16 portfolios, considered as dependent variables in the time series regressions. It shows that the portfolios in the smallest size quintile and the lowest book to market quintile and these in the biggest size quintile and the highest book to market quintile contain, on average, less stocks than other portfolios. Like table 1 in Fama and French (1993), in the smallest (biggest) size quintile, the number of stocks increases (decreases) from lower to higher book to market portfolios.

\section{[Insert table 3 here]}




\section{Size And Book to Market Effects: Further Evidence}

The average excess returns of the 16 stock portfolios considered range from $0.81 \%$ to $2.71 \%$ per month. The positive relation between average excess returns and book to market equity is confirmed. For every size class, average returns of high book to market group are higher than these of low book to market group ${ }^{17}$. Like Molay (1999), in every book to market quintile, average excess returns of small capitalizations are higher than these if big ones. This observation confirms the evidence that there is a negative relation between size and average return. All excess returns of portfolios have high standard deviations (greater than $6 \%$ per month). All portfolios produce average excess monthly returns that are more than two standard errors from zero.

On the basis of the adjusted $R^{2}$ criterion, we can affirm that the three factor model captures common variation in stock returns ${ }^{18}$. Indeed, for the sixteen portfolios, we obtained an average adjusted $R^{2}$ about $68.5 \%$. The market $\beta$ s are all more than 9 standard errors from zero and adjusted $R^{2}$ ranges from $52.0 \%$ to $85.7 \%$. Moreover, $H M L$ slopes are related to book to market ratio. For all size classes, they increase from negative values for the lowest book to market quintile to positive values for the highest book to market quintile. Their t-statistics are greater than two, in absolute value, in seven cases. Similarly, $S M B$ slopes are related to size. In every book to market quintile, they decrease from positive values with small capitalizations to negative values with big class. They are more than two standard errors from zero, in absolute value, in thirteen cases out of sixteen.

Fama and French (1993) argue that the multi-factor asset pricing models of Merton (1973) and Ross (1976) imply a simple test of whether the set of explanatory 
variables suffice to describe the cross-section of average returns: intercepts of timeseries regressions should be close to zero. In twelve cases out of sixteen, intercepts are below two standard errors from zero ${ }^{19}$. To sum up our results, we can say that the regressions of the three factor model absorb common time-series variation in returns (slopes and adjusted $R^{2}$ values). Moreover, because of intercepts which are close to zero, they explain the cross-section of average returns.

[Insert table 4 here]

\section{Size, Book to Market and Borrowing Ratio Sorted Portfolios}

4.1. Database and Methodology. The aim of this sub-section is to present the methodology used to construct the leverage factor for our sample. In their empirical investigation, Ferguson and Shockley (2003) propose two mesures to capture the missed beta risk. The first portfolio is based on the ratio debt to equity and it is associated to relative leverage. The second one, based on Altman's Z-score, is used to express the relative distress. As the two authors mentioned, this distinction between relative leverage and relative distress is important. We are aware about that. Nevertheless, the database enables us to construct only the leverage portfolio. For our 636 stocks, only 341 have data about their borrowing ratio ${ }^{20}$. Because of Datastream data limitations, the period covered is only from July 1984 to June 2001 (204 months).

Each year, stocks are assigned to one of three classes of borrowing ratio. The average annual number of stocks in each group is about 48. It ranges from 8 to 105. The average annual borrowing ratio is about 0.314 for low group, 0.963 for medium one and 10.422 for high group. In each month, we calculate the average 


\section{Size And Book to Market Effects: Further Evidence}

value-weight return of the three classes of borrowing ratio, high, medium and low. The return of the leverage portfolio $(\mathrm{L})$ is calculated as the difference, the return of high borrowing ratio portfolio minus the return of low borrowing ratio portfolio, divided by two.

[Insert table 5 here]

The average return of the leverage portfolio (L) is only about $0.09 \%$ per month $(t=0.519)$ for the period from July 1984 to June 2001. Table 5 documents that the $H M L$ portfolio and the leverage portfolio $L$ have the highest correlation and it is about 0.296 . This correlation can be understood as follows: when high book to market firms outperform low book to market ones, firms with high borrowing ratio would outperform these with low ratio. As for $S M B$ portfolio, it has negative correlation with $L$ portfolio. The second highest correlation is about 0.189 and it is between $S M B$ and $H M L$ portfolios.

\section{[Insert table 6 here]}

Table 6 shows time-series regressions of market, $H M L$ and $S M B$ on the leverage portfolio $L$. The highest value of adjusted $R^{2}$ is about $8.32 \%$ and it is relative to the time-series regression of the $H M L$ portfolio. For the two other regressions, the coefficients of the leverage portfolio aren't significantly different from zero and the adjusted $R^{2}$ are only about $0.76 \%$ and $0.68 \%$. Time variation in leverage portfolio returns doesn't help to explain time variation in returns of market, $H M L$ and $S M B$. In the same scope of ideas, we regress monthly returns of the leverage portfolio on the $S M B$ and $H M L$ returns. $S M B$ and $H M L$ portfolios explain only $10.7 \%$ of leverage portfolio. Only the coefficient of $H M L$ is significantly different from zero 
with a t-statistic of 3.076 and it is about 0.132 . As for $S M B$, the slope is about $-0.088($ t-statistic $=-1.809)$.

The time-series regressions of table 6 enable us to define two portfolios, $S M B^{\perp}$ and $H M L^{\perp}$. Like Ferguson and Shockley (2003), $S M B^{\perp}$ is the $S M B$ factor orthogonal to the leverage portfolio. It is calculated as the sum of the estimated intercept plus the monthly residual from the time series regression $S M B=\alpha_{i}+d_{i} L+\epsilon_{i}$. As for the $H M L^{\perp}$ portfolio, it is the $H M L$ factor orthogonal to the leverage portfolio and it is calculated in same manner. It equals the estimated intercept plus the monthly residual from the time-series regression $H M L=\alpha_{i}+d_{i} L+\epsilon_{i}$. We define also the leverage portfolio orthogonal to $S M B$ and $H M L$ portfolios, or $L^{\perp}$. Each month, we sum the estimated intercept with the residual from the time-series regression $L=\alpha_{i}+s_{i} S M B+h_{i} H M L+\epsilon_{i}$. These portfolios are used as explanatory variables in the time-series regressions of the next sub-section.

First, we regress monthly excess returns of the sixteen portfolios on the monthly excess returns of the market and the leverage portfolios (see table 7 ). The average adjusted $R^{2}$ for all time-series regressions is about $55.93 \%$. It ranges from $11.8 \%$ for the portfolio in the second quintile of size and of high book to market ratio to $90.1 \%$ for big/low book to market portfolio. The market $\beta$ s are all more than two standard errors from zero. Moreover, leverage slopes haven't a particular pattern. Only three out of sixteen are significantly different from zero. The cross-sectional dispersion in leverage estimated coefficients is large. In Ferguson and Shockley (2003), it is about 0.84 . In our sample, the highest slope is about 0.921 and the lowest one is about -1.548 . 


\title{
Size And Book to Market Effects: Further Evidence
}

\author{
[Insert table 7 here]
}

4.2. Empirical Results: Market, $H M L, S M B$ and Leverage Factors. In this sub-section, we present cross-section and time-series regressions of the CAPM, the three factor model and a model with the leverage portfolio. First of all, we show the time-series regressions for the sixteen portfolios described earlier on the market, $S M B, H M L$ and leverage portfolios.

In Ferguson and Shockley (2003), leverage mesures do not help explain returns in time-series however they do a good job in cross-section. The two authors explain that such a result isn't surprising because of the very low average returns on leverage and distress portfolios which lead to large pricing errors.

Using least squares and White heteroskedasticity consistent standard errors and covariance, we regress monthly returns of the 16 portfolios according to:

$$
R_{i}-R_{f}=\alpha_{i}+\beta_{i}\left(R_{M}-R_{f}\right)+d_{i} L+s_{i} S M B^{\perp}+h_{i} H M L^{\perp}+\epsilon_{i} .
$$

Table 8 shows the coefficients and their $t$ statistics (between brackets), the adjusted $R^{2}$ and the statistic of Durbin-Watson of the 16 time-series regressions. $S M B^{\perp}$ and $H M L^{\perp}$ are the portions of $S M B$ and $H M L$ portfolios orthogonal to the leverage portfolio.

Only three intercepts out of sixteen are significantly different from zero. The portion of the $S M B$ portfolio orthogonal to the leverage portfolio helps in explaining the time variation of portfolio returns. The $S M B^{\perp}$ coefficients are more than two 
standard errors from zero in twelve cases. As for the $H M L^{\perp}$ coefficients, the results are less significant because only eight slopes are significantly different from zero.

These observations offer a preliminary conclusion concerning the marginal contribution of $S M B^{\perp}$ and $H M L^{\perp}$ portfolios in explaining stock returns. We note that the portions of $S M B$ and $H M L$ orthogonal to the leverage portfolio are significant. The leverage portfolio doesn't capture the total size and value premiums.

Furthermore, the slopes of the $S M B$ portfolio in the smallest groups are higher than these of the biggest ones. The $H M L$ slopes are also related to the book to market group because they are increase from negative values for the classes of low book to market ratio to positive values for the classes of high ratio. The leverage slopes don't show a particular pattern in relation to the size and book to market classification however they are statistically significant (two standard error above zero) in seven cases. After removing the variation common with the leverage portfolio, $S M B$ and $H M L$ factors keep explanatory power in the time-series regressions of the portfolio returns.

[Insert table 8 here]

The second hypothesis to test is the marginal contribution of the leverage portfolio in the time-series regressions after controlling for the portion related to $S M B$ and $H M L$. Table 9 summarizes the results of this test. In the same way, using least squares and White heteroskedasticity consistent standard errors and covariance, we regress monthly returns of the 16 portfolios according to:

$$
R_{i}-R_{f}=\alpha_{i}+\beta_{i}\left(R_{M}-R_{f}\right)+d_{i} L^{\perp}+s_{i} S M B+h_{i} H M L+\epsilon_{i} .
$$




\section{Size And Book to Market Effects: Further Evidence}

The table shows the coefficients and their $t$ statistics (between brackets), the adjusted $R^{2}$ and the statistic of Durbin-Watson of the 16 time-series regressions. As we have mentioned before, $L^{\perp}$ is the portion of the leverage portfolio orthogonal to $S M B$ and $H M L$ portfolios.

The main observation from the table is that even after controlling the portion related to $S M B$ and $H M L$ portfolios, the leverage portfolio still significant in six cases out of sixteen. Moreover, the leverage slopes don't show a particular pattern in relation to the size and book to market classification. The size and book to market portfolios don't capture the leverage effect. Moreover, adding the leverage factor to the three factor model increases the adjusted $R^{2}$ in twelve time-series regressions out of sixteen. In order to get more conclusive observations, we present the results of cross-section regressions.

\section{[Insert table 9 here]}

Indeed, we use the two-pass methodology of Fama and MacBeth (1973). For each of the 16 portfolios, we regress monthly excess returns on the explanatory variables in a time series regression. We specify five models: the CAPM, a model with the market and the leverage portfolios, the three factor model, a model with the market, the leverage, $S M B^{\perp}$ and $H M L^{\perp}$ and a model with the market, $L^{\perp}, S M B$ and $H M L$ portfolios. The time-series regressions are made for a period of five years (the estimation period) and they are repeated each month (July 1984/June 1989, August 1984/July 1989, etc). The coefficient estimates from the first step $\left(\hat{\beta}_{i}\right)$ are then used as the explanatory variables in a series of 144 cross-sectional regressions. For each month, we regress the monthly excess returns of the 16 portfolios on the 
coefficients estimates $\left(\hat{\beta}_{i}\right)$. For example, we regress the monthly excess returns of the 16 portfolios of July 1989 on the coefficients estimates $\left(\hat{\beta}_{i}\right)$ of the period July 1984/June 1989. Then, we define the slope estimates for the overall crosssectional model as the average of the second pass coefficient estimates $\left(\hat{\gamma}_{j}\right)$. As Fama and MacBeth, the t-statistics of these coefficients are calculated as follows:t $\left(\overline{\hat{\gamma}_{j}}\right)=$ $\frac{\overline{\gamma_{j}}}{\operatorname{std}\left(\hat{\gamma_{j}}\right) / \sqrt{n}}$ where $n$ is the number of months.

All results are shown in table 10. Panel A in table 10 presents the traditional CAPM. The average $R^{2}$ of the 144 cross-sectional regressions is about $11.12 \%$. After adding the $S M B$ and $H M L$ portfolios, the explanatory power of the model increases and it is, on average, equal to $34.22 \%$ (panel B). Panel $\mathrm{C}$ of the table presents the empirical results of the model suggested by Ferguson and Shockley. The estimated return per unit $\beta_{i}^{L}$ risk isn't large and it is negative. Its t-statistic is about -1.133. In panels $\mathrm{D}$ and $\mathrm{E}$, we distinguish the effects of the leverage portfolio from the $S M B$ and $H M L$ ones.

Indeed, panel D of table 10 presents the results of the model that includes the market, $S M B, H M L$ factors and the orthogonalized leverage portfolio. The estimated return per unit $\beta_{i}^{L^{\perp}}$ risk is positive and is less than one standard error above zero. Furthermore, the return per unit $S M B$ risk is positive and it is statistically significant. Both the estimates return per unit $H M L$ risk and $\beta_{i}^{M k t}$ risk are negative and less than two standard error above zero. After removing the common variation with the leverage portfolio, the question is to know if the estimates returns per unit $S M B$ and $H M L$ risks change. In panel E, we answer that question. We present the results of the model that includes the market, the leverage, the orthogonalized 


\section{Size And Book to Market Effects: Further Evidence}

$S M B$ and $H M L$ factors. Panel D as well as panel E explain, on average, $40.25 \%$ of cross-sectional regressions. The estimated return per unit $\beta_{i}^{L}$ risk is still positive and is less than one standard error above zero. After removing the common variation with the leverage factor, $S M B$ is no longer significantly different from zero however it still the highest premium. Furthermore, the estimated return per $H M L$ and $\beta_{i}^{M k t}$ risks still negative.

[Insert table 10 here]

In figures 1 to 5 (see the appendix), we construct fitted versus actual average monthly excess returns of the 16 portfolios for the five cross-sectional models in table 10. We mesure the additional improvement of a model by the number of the plotted points around the diagonal. The three factor model is better then the model with the market and the leverage portfolios. Nevertheless, figures 4 and 5 show that the leverage portfolio give additional improvement to three factor model. The plotted points are more tighten around the diagonal.

\section{Discussion and Conclusions}

Financial literature provides many explanations to size and value premiums. Unlike Fama and French (1993), authors of the three factor model, who argue that market, $S M B$ and $H M L$ portfolios explain stock returns, Ferguson and Shockley (2003) discuss in depth the question of the true market portfolio. They provide a theoretical framework explaining that the size and book to market effects are due to bad market proxies. As long as the market proxy doesn't incorporate the economy's debt claims, these effects are expected to be found in any database. HML and SMB 
portfolios are related to the missing factor of risk. They loose any explanatory power in the presence of the leverage and distress portfolios.

In this paper, our primary contribution is to provide an empirical analysis of Ferguson and Shockley (2003) theoretical framework on the French stock market. The aim is to study the market, $S M B, H M L$ and the leverage factors in explaining cross-sectional and time-series returns. Because of a database limitation, we construct only one leverage mesure, based on a borrowing ratio classification. The period is from July 1984 to June 2001.

Unlike Ferguson and Shockley (2003), our main result is that the leverage factor doesn't subsume the $S M B$ and $H M L$ factors. In cross-sectional regressions, only the size premium is statistically significant and help explaining returns. In timeseries regressions, the three factors $(S M B, H M L$ and leverage), with the market portfolio, do a good job. This result suggests that the theoretical framework of Ferguson and Shockley (2003) is worth interesting however it is insufficient. The leverage portfolio has an additional improvement of the model. Nevertheless, it doesn't explain the $S M B$ and $H M L$ factors in the French case.

One limit of our study is the use of only one mesure for the firm's leverage. The question is to ask about the additional improvement of the results with a portfolio based on the relative distress. I don't think that such a portfolio will change dramatically the results. Our argument in favor of a such affirmation is the little change in the estimated per unit $H M L$ risk after adding the leverage mesure, despite the high correlation between the leverage and $H M L$ portfolios. 


\section{Size And Book to Market Effects: Further Evidence}

\section{Footnotes}

[1] Schwert (1983): "The search for an explication of this anomaly has been unsuccessful. Almost all authors of papers on the 'size effect' agree that it is evidence of misspecification of the capital asset pricing model, rather than evidence of inefficient capital markets. On the other hand, none of the attempts to modify the CAPM to account for taxation, transaction costs, skewness preference, and so forth have been successful at discovering the 'missing factor' for which size is a proxy. Thus, our understanding of the economic or statistical causes of the apparently high average returns to small firms' stocks is incomplete. It seems unlikely that the 'size effect' will be used to measure the opportunity cost of risky capital in the same way the CAPM is used because it is hard to understand why the opportunity cost of capital should be substantially higher for small firms than for large firms."

[2] The question of anomalies is much debated in finance. Nevertheless, as Kuhn (1962) said: "Discovery commences with the awareness of anomaly, i.e., with the recognition that nature has somehow violated the paradigm-induced expectations that govern normal science. It then continues with a more or less extended exploration of the area of anomaly. And it closes only when the paradigm theory has been adjusted so that the anomalous has become the expected.".

[3] The conditional version of the model authorizes a temporal variation of the rate of stock returns and coefficients of the factors of risk.

[4] Gross National Product: Chen (1991) indicate that the expected stock returns are negatively correlated with the present rate of growth of GNP and positively correlated with its future rate of growth. 
[5] we limit the presentation to three biais related to the use of the data but there exists others; such as errors of corresponding market and accounting data or look ahead bias.

[6] Fama and French (1996b) and Fama and French (1996a) give four arguments: the premium of the financial distress is not special to a particular sample since it is checked for different periods. It was also the subject of many studies made on international database. The size, book to market equity, earning to price and cash flow ratios, indicators of expected incomes (Ball 1978), have a great utility to test models of asset pricing like the CAPM. And in fourth point, the limited number of the anomalies excludes the assumption ofdata-mining.

[7]Barber and Lyon (1997) confirmed the relation between the size, the book to market ratio and the stock returns, published by Fama and French (1992), for the financial institutions (Fama and French considered only the non-financial firms).

[8] See also Daniel et al. (2001). In the French case, see Lajili (2003a) and Lajili (2003b)

[9]Stocks with negative book to market are eliminated.

[10] Market value to Book divides the Market Value by the Net Book Value (Net Tangible Asset). For companies which have more than one classe of equity capital, both market value and net tangible asset are expressed according to the individual issue.

[11]Market Value is defined as the share price multiplied by the number of ordinary shares issue. The amount in issue is updated whenever new tranches of stock are issued or after a capital change. 


\section{Size And Book to Market Effects: Further Evidence}

[12] See Berk (1995) and Berk (1997).

[13] $R_{p, t}=\sum_{i=1}^{n} \omega_{i, t} * R_{i, t}$. Where:

$R_{p, t}$ : is the value-weight monthly return of portfolio $p$ in month $t$.

$R_{i, t}$ : is the monthly return of stock $i$ of portfolio $p$ in month $t$.

$\omega_{i, t}$ : is the ratio of market value of stock $i$ on total value market of portfolio $p$ in month $t$.

$n$ : is the number of stocks of portfolio $p$.

[14] Molay (1999) documented an average excess return for the market portfolio of only $0.31 \%$.

[15] Heston et al. (1999) study the case of France (among 12 European countries) for the period from 1978 to 1995 . There sample has 418 stocks.

[16] Molay (1999) documented that this negative correlation between $S M B$ and market portfolio can be explained by the fact that market portfolio is value weighted. When we consider an equal weighted portfolio, this correlation become positive (and it is about 0.13 in Molay's study).

[17] In a first publication on the French market (204 stocks) for the period from July 1992 to June 1997, Molay (1999) confirms the negative relation between size and average return, however he does not found any relation between book to market ratio and average return. Standard deviation of excess stock portfolio returns in his study are less than these of our sample. Molay (2001) considers the period from July 1988 to June 1998 (120 months) for an average of 250 stocks and he confirmed the negative size/average returns relation for only high book to market classes and the positive book to market/average returns relation for only small capitalizations. 
[18]For further results on the comparaison between the three factor model and the CAPM, see Lajili (2002) and Lajili (2003b).

[19] Molay (1999) and Molay (2001), obtained two regressions of the three factor model out of nine where intercepts are more than two standard errors from zero.

[20]Stocks with negative borrowing ratio are eliminated. 


\section{Size And Book to Market Effects: Further Evidence}

\section{REFERENCES}

BALL, R. (1978). 'Anomalies in relationships between securities' yields and yieldsurrogates.' Journal of Financial Economics, (6): pp. 103-26.

BAnz, R. (1981). 'The Relationship between Return and Market Value of Common Stocks.' Journal of Financial Economics, (9): pp. 3-18.

BARBER, B. and J. LYON (1997). 'Firm size, book-to-market ratio, and security returns : a holdout sample of financial firms.' The Journal of Finance, LII (2): pp. $875-83$.

BASU, S. (1977). 'Investment Performance of Common Stocks in Relation to their Price-Earnings Ratios: A Test of the Efficient Market Hypothesis.' Journal of Finance, XXXII (3): pp. 663-82.

BASU, S. (1983). 'The relationship between earnings' yield, market value and return for NYSE common stocks.' Journal of Financial Economics, (12): pp. 129-56.

Berk, J. (1995). 'A critique of size-related anomalies.' The Review of Financial Studies, 8 (2): pp. 275-86.

Berk, J. (1997). 'Does Size Really Matter?' Financial Analysts Journal, pp. 12-18.

Berk, J., R. Green and V. NAik (1999). 'Optimal Investment, Growth Options, and Security Returns.' Journal of Finance, LIV (5): pp. 1553-607.

Bhandari, L. (1988). 'Debt/Equity Ratio and Expected Common Stock Returns: Empirical Evidence.' Journal of Finance, XLIII (2): pp. 507-28.

Black, F. (1972). 'Capital Market Equilibrium with Restricted Borrowing.' Journal of Business, (45): pp. 444-55.

Black, F. (1993a). 'Beta and Return.' Journal of Portfolio Management, 20 (1): 
pp. 9-18.

Black, F. (1993b). 'Estimating Expected Return.' Financial Analysts Journal, 49: pp. 36-38.

Breeden, D. (1979). 'An Intertemporal Asset Pricing Model With Stochastic Consumption and Investment Opportunities.' Journal of Financial Economics, (7): pp. 265-96.

Chan, L., Y. Hamao and J. Lakonishok (1991). 'Fundamentals and stock returns in Japan.' The Journal of Finance, XLVI (5): pp. 1739-64.

Chen, N. (1991). 'Financial investment opportunities and the macroeconomy.' The Journal of Finance, XLVI (2): pp. 529-54.

Cochrane, J. (2001). Asset Pricing. Princeton University Press.

Daniel, K. and S. Titman (1997). 'Evidence on the characteristic of cross sectional variation in stock return.' The Journal of Finance, LII (1): pp. 1-33.

Daniel, K., S. Titman and K. Wei (2000). 'Explaining the Cross-Section of Stock Returns in Japan: Factors or Characteristics?' Working Papers, pp. 1-30.

Daniel, K., S. Titman and K. Wei (2001). 'Explaining the Cross-Section of Stock Returns in Japan: Factors or Characteristics?' Journal of Finance, LVI (2): pp. $743-66$.

Davis, J., E. FAma and K. French (2000). 'Characteristics, covariances, and average returns : 1929 to 1997.' The Journal of Finance, LV (1): pp. 389-406.

FAmA, E. (1991). 'Efficient capital markets: II.' The Journal of Finance, XLVI (5): pp. $1575-617$.

FAma, E. and K. French (1991). 'The cross section of expected stock returns.' 


\section{Size And Book to Market Effects: Further Evidence}

Unpublished manuscript, Graduate School of Business, University of Chicago.

FAma, E. and K. French (1992). 'The cross section of expected stock returns.' The Journal of Finance, XLVII (2): pp. 427-65.

Fama, E. and K. French (1993). 'Common risk factors in the returns on stocks and bonds.' Journal of Financial Economics, 33: pp. 3-56.

Fama, E. and K. French (1996a). 'The CAPM is wanted, dead or alive.' The Journal of Finance, LI (5): pp. 1947-58.

FAma, E. and K. French (1996b). 'Multifactor explanations of asset pricing anomalies.' The Journal of Finance, LI (1): pp. 55-84.

FAmA, E. and J. MacBeth (1973). 'Risk, Return, and Equilibrium: Empirical Tests.' Journal of Political Economy, pp. 607-36.

Ferguson, M. and R. Shockley (2003). 'Equilibrium "Anomalies".' Journal of Finance, Forthcoming: pp. 1-49.

GraueR, R. (1999). 'On the cross-sectional relation between expected returns, betas, and size.' The Journal of Finance, LIV (2): pp. 773-89.

Heston, S., K. Rouwenhorst and R. Wessels (1999). 'The role of beta and size in the cross-section of european stock returns.' European Financial Management, $5(1)$ : pp. $9-27$.

KIM, D. (1997). 'A reexamination of firm size, book to market, and earnings price in the cross-section of expected stock returns.' Journal of Financial and Quantitative Analysis, 32 (4): pp. 463-89.

Kothari, S., J. Shanken and R. Sloan (1995). 'Another look at the cross-section of expected stock returns.' The Journal of Finance, L (1): pp. 185-224. 
Kunn, T. (1962). The Structure of Scientific Revolutions, chap. Anomaly and the Emergence of Scientific Disciveries, pp. 52-65. The University of Chicago Press, third, 1996 ed.

LAJILI, S. (2002). 'The Capital Asset Pricing Model and the three Factor Model of Fama and French revisited in the case of France.' Cahier de Recherche du CEREG, Université Paris IX Dauphine, (2002-10): pp. 1-26.

LAJILI, S. (2003a). 'Explaining the Cross-Section Returns in France: Characteristics or Covariances?' Cahier de Recherche du CEREG, Université Paris IX Dauphine, (2003-05): pp. 1-26.

LAJILI, S. (2003b). Modélisation quantitative des marchés financiers: quatre essais sur le modèle à trois facteurs dans le cas français. Ph.D. thesis, University Paris Dauphine.

Lakonishok, J., A. Shleifer and R. Vishny (1994). 'Contrarian Investment, Extrapolation, and Risk.' Journal of Finance, XLIX (5): pp. 1541-78.

LEWELlEn, J. (1999). 'the time series relations among expected return, risk, and book to market.' Journal of Financial Economics, 54: pp. 5-43.

LintneR, J. (1965). 'The Valuation of Risk Assets and the Selection of Risky Investments in Stock Portfolios and Capital Budgets.' Review of Economics and Statistics, (47): pp. 13-37.

Litzenberger, R. and R. K. (1979). 'The effect of personal taxes and dividends on capital asset prices: Theory and Empirical Evidence.' Journal of Financial Economics, (7): pp. 163-95.

Lo, A. and A. MacKinlay (1990). 'Data-Snooping Biases in Tests of Financial 


\section{Size And Book to Market Effects: Further Evidence}

Asset Pricing Models.' Review of Financial Studies, 3 (3): pp. 431-67.

LuCAs, R. (1978). 'Asset Prices in an Exchange Economy.' Econometrica, 46 (6): pp. $1429-45$.

MacKinlay, A. (1995). 'Multifactor models do not explain deviations from the CAPM.' Journal of Financial Economics, 38: pp. 3-28.

Merton, R. (1973). 'An Intertemporal Capital Asset Pricing Model.' Econometrica, 41 (5): pp. 867-87.

Molay, E. (1999). 'le modèle de rentabilité à trois facteurs de Fama et French (1993) : le cas français.' Working Papers, CEROG, Aix-Marseille, pp. 1-27.

Molay, E. (2001). Modélisation Empirique de la Rentabilité: Le Modèle à Trois Facteurs, Une Alternative au Modèle de Marché?. Thèse en sciences de gestion, Université de Droit, d'Economie et des Sciences d'Aix-Marseille.

Mossin, J. (1966). 'Equilibrium In A Capital Asset Market.' Econometrica, 34 (4): pp. $768-83$.

Nicholson, S. (1960). 'Price-earnings ratios.' Financial Analysts Journal.

Nicholson, S. (1968). 'Price-earnings in relation to investment results.' Financial Analysts Journal.

Reinganum, M. (1981). 'Misspecification of Capital Asset Pricing: Empirical Anomalies Based on Earnings' Yields and Market Values.' Journal of Financial Economics, (9): pp. 19-46.

Roll, R. (1977). 'A Critique Of The Asset Pricing Theory's Tests.' Journal of Financial Economics, (4): pp. 129-76.

Ross, S. (1976). 'The Arbitrage Theory of Capital Asset Pricing.' Journal of 
Economic Theory, (13): pp. 341-60.

Rubinstein, M. (1976). 'The Strong Case for The Generalized Logarithmic Utility Model as the Premier Model of Financial Markets.' Journal of Finance, (2): pp. $551-71$.

Schwert, G. (1983). 'Size and stock returns, and other empirical regularities.' Journal of Financial Economics, 12: pp. 3-12.

Sharpe, W. (1964). 'Capital Asset Prices: A Theory of Market Equilibrium Under Conditions of Risk.' The Journal of Finance, XIX (3): pp. 425-42.

Stattman, D. (1980). 'Book values and expected stock returns.' The Chicago MBA, A Journal of Selected Papers, (4): pp. 25-45.

\section{APPENDIX}


Size And Book to Market Effects: Further Evidence

Table 8. (Continued)

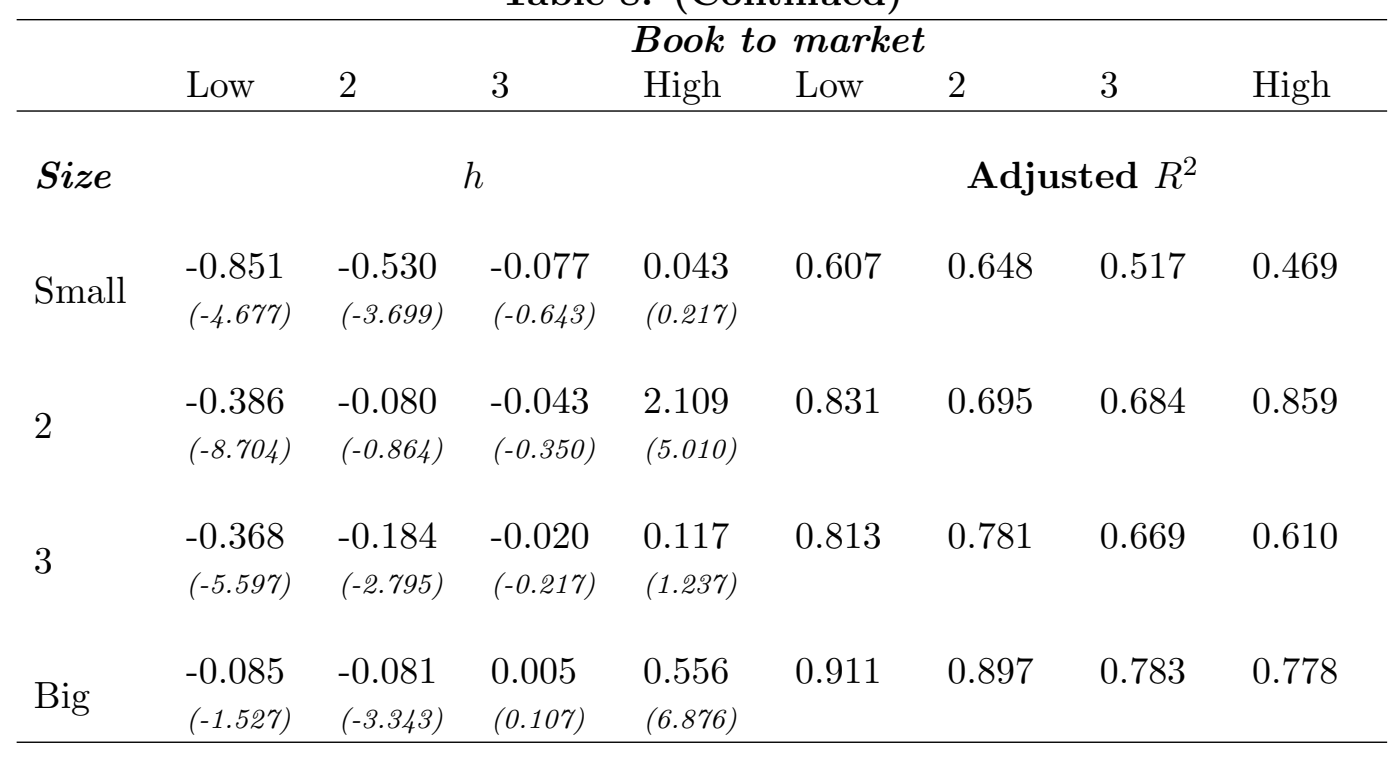

\section{Durbin Watson}

\begin{tabular}{lllll} 
Small & 1.962 & 1.940 & 1.685 & 1.867 \\
2 & 1.919 & 2.096 & 1.918 & 1.909 \\
3 & 2.126 & 1.709 & 2.234 & 2.136 \\
Big & 2.021 & 2.067 & 2.161 & 1.996 \\
\hline
\end{tabular}


Table 9. (Continued)

\begin{tabular}{|c|c|c|c|c|c|c|c|c|}
\hline & \multicolumn{8}{|c|}{ Book to market } \\
\hline & Low & 2 & 3 & High & Low & 2 & 3 & High \\
\hline Size & \multicolumn{4}{|c|}{$h$} & \multicolumn{4}{|c|}{ Adjusted $R^{2}$} \\
\hline Smoll & -0.872 & -0.658 & -0.095 & 0.081 & 0.607 & 0.648 & 0.517 & 0.469 \\
\hline N11001 & $(-5.229)$ & $(-4.307)$ & $(-0.842)$ & $(0.422)$ & & & & \\
\hline \multirow{3}{*}{2} & -0.388 & -0.065 & -0.001 & 2.085 & 0.831 & 0.695 & 0.684 & 0.859 \\
\hline & $(-$ & $(-0.705)$ & $(-0.010)$ & $(5.105)$ & & & & \\
\hline & 10.402) & & & & & & & \\
\hline \multirow{2}{*}{3} & -0.415 & -0.204 & 0.003 & 0.163 & 0.813 & 0.781 & 0.669 & 0.610 \\
\hline & $(-5.693)$ & $(-2.848)$ & $(0.031)$ & $(1.753)$ & & & & \\
\hline \multirow{2}{*}{ Big } & -0.093 & -0.051 & 0.017 & 0.481 & 0.911 & 0.897 & 0.783 & 0.778 \\
\hline & $(-1.613)$ & $(-2.260)$ & $(0.408)$ & $(7.076)$ & & & & \\
\hline
\end{tabular}

\section{Durbin Watson}

\begin{tabular}{lllll} 
Small & 1.962 & 1.940 & 1.685 & 1.867 \\
2 & 1.919 & 2.096 & 1.918 & 1.909 \\
3 & 2.126 & 1.709 & 2.234 & 2.136 \\
Big & 2.021 & 2.067 & 2.161 & 1.996 \\
\hline
\end{tabular}




\section{Size And Book to Market Effects: Further Evidence}

TABLE 1.

Descriptive Statistics for Six Stock Portfolios Formed From Independent Sorts on Size and Book to Market: July 1976/June 2001 (300 months)

The sample is composed of 636 French stocks. The six size-book to market portfolios are formed from independent sorts on book to market and size as described in the text. The table gives some characteristics of these six portfolios. Average annual market value is in millions of euros. The monthly returns of $H M L$ correspond to: $H M L=\{(H S+$ $H B)-(L S+L B)\} / 2$. As for the monthly returns of $S M B$, it corresponds to: $S M B=$ $\{(H S+M S+L S)-(H B+M B+L B)\} / 3$. The market portfolio (Mktpond.) is the value-weight returns of all stocks of the sample. The table gives correlations, average monthly excess returns, standard deviation and $t$-statistic for means $($ mean $=0)$ and an equality test of means for these three explanatory variables.

\begin{tabular}{|c|c|c|c|}
\hline & \multicolumn{3}{|c|}{ Book to Market equity quintiles } \\
\hline & $\mathrm{L}$ & M & $\mathrm{H}$ \\
\hline Size & \multicolumn{3}{|c|}{ Annual Average Market Value } \\
\hline $\mathrm{S}$ & 104.99 & 93.65 & 77.49 \\
\hline \multirow[t]{2}{*}{ B } & 1763.91 & 1396.05 & 1071.28 \\
\hline & \multicolumn{3}{|c|}{ Annual Average Book to Market ratio } \\
\hline$\overline{\mathrm{S}}$ & 0.100 & 0.596 & 1.476 \\
\hline \multirow[t]{2}{*}{ B } & 0.142 & 0.574 & 1.343 \\
\hline & \multicolumn{3}{|c|}{ Annual Average Number of Stocks } \\
\hline S & 22.2 & 41.0 & 40.0 \\
\hline B & 39.6 & 41.7 & 22.0 \\
\hline
\end{tabular}


Table 1. (continued) Explanatory variables Correlations

\begin{tabular}{llll} 
& Mktpond. & HML & SMB \\
Mktpond. & 1.00 & & \\
HML & 0.079 & 1.00 & \\
SMB & -0.121 & 0.164 & 1.00 \\
\hline & Monthly Excess Returns (in percent) & \\
& & \\
& Mktpond. & HML & SMB \\
Mean & 1.134 & 0.597 & 0.742 \\
Standard Deviation & 6.221 & 5.880 & 4.637 \\
$t$-statistic for means & 3.157 & 1.758 & 2.771 \\
\hline & \multicolumn{2}{c}{ Test Equality } & of Means \\
& & & \\
& Mktpond. & HML & SMB \\
Mktpond. & - & & \\
HML & 1.086 & - & - \\
SMB & 0.875 & 0.335 & \\
\hline
\end{tabular}


Size And Book to Market Effects: Further Evidence

TABLE 2 .

\section{Some Characteristics of The 16 Portfolios: From July 1976 to June 2001 (300 months)}

\footnotetext{
The sample is composed of 636 French stocks. The 16 portfolios are obtained from independent sorts on size and book to market. The table gives average annual market value (in millions of euro), average annual book to market, average annual number of stocks for these portfolios.
}

Book to Market

\begin{tabular}{|c|c|c|c|c|}
\hline & Low & 2 & 3 & High \\
\hline Size & \multicolumn{4}{|c|}{ Average Annual Market Value } \\
\hline Small & 49.76 & 44.70 & 46.06 & 39.97 \\
\hline 2 & 145.53 & 138.56 & 134.45 & 130.82 \\
\hline 3 & 355.50 & 349.93 & 341.36 & 328.17 \\
\hline \multirow[t]{2}{*}{ Big } & 2983.66 & 2726.66 & 2063.16 & 2361.00 \\
\hline & \multicolumn{4}{|c|}{ Average Annual Book to Market } \\
\hline Small & 0.082 & 0.454 & 0.777 & 1.769 \\
\hline 2 & 0.094 & 0.463 & 0.779 & 1.430 \\
\hline 3 & 0.144 & 0.457 & 0.762 & 1.447 \\
\hline \multirow[t]{2}{*}{ Big } & 0.118 & 0.451 & 0.767 & 1.517 \\
\hline & \multicolumn{4}{|c|}{ Average Annual Number of Stocks } \\
\hline Small & 7.72 & 10.4 & 14.72 & 19.44 \\
\hline 2 & 10.52 & 12.36 & 13.4 & 15.12 \\
\hline 3 & 14.16 & 14 & 12.56 & 10.72 \\
\hline Big & 19.2 & 14.76 & 10.76 & 6.8 \\
\hline
\end{tabular}


TABLE 3.

Summary Statistics For Monthly Excess Returns of The 16 Portfolios: From July 1976 to June 2001 (300 months)

The sample is composed of 636 French stocks. The 16 portfolios are obtained from independent sorts on size and book to market. The table gives average monthly excess returns, standard deviation, Sharpe ratio and $t$-statistics for the equality test of means to zero.

Book to Market

\begin{tabular}{lcccc}
\hline & Low & 2 & 3 & High \\
\hline & & & \\
Size & & Mean Monthly Excess Returns (in percent) \\
Small & 1.37 & 2.44 & 2.05 & 2.61 \\
2 & 1.39 & 1.03 & 1.23 & 2.71 \\
3 & 1.03 & 0.99 & 0.94 & 1.73 \\
Big & 0.81 & 1.15 & 1.09 & 0.99 \\
\hline
\end{tabular}

\begin{tabular}{llccc} 
& & Standard Deviation of Monthly Excess & Returns \\
Small & 11.50 & 10.18 & 7.63 & 8.03 \\
2 & 7.78 & 6.35 & 7.15 & 18.98 \\
3 & 7.27 & 7.03 & 6.58 & 7.78 \\
Big & 6.63 & 8.56 & 7.03 & 8.30 \\
\hline
\end{tabular}

\begin{tabular}{llrrr} 
& & & Sharpe Ratio \\
Small & 11.91 & 23.96 & 26.86 & 32.50 \\
2 & 17.86 & 16.22 & 17.20 & 14.27 \\
3 & 14.16 & 14.08 & 14.30 & 22.23 \\
Big & 12.21 & 13.43 & 15.50 & 11.92 \\
\hline
\end{tabular}

\begin{tabular}{lllrl} 
& & \multicolumn{3}{c}{ t-statistic } \\
Small & 2.070 & 4.160 & 4.657 & 5.634 \\
2 & 3.093 & 2.814 & 2.988 & 2.479 \\
3 & 2.464 & 2.451 & 2.476 & 3.854 \\
Big & 2.117 & 2.326 & 2.699 & 2.082 \\
\hline
\end{tabular}




\section{Size And Book to Market Effects: Further Evidence}

TABLE 4.

\section{Three Factor Regressions of Monthly Excess Returns of The 16 Portfolios: From July 1976 to June 2001 (300 months)}

The sample is composed of 636 French stocks. The sixteen size-book to market portfolios are formed from independent sorts on size and book to market ratio. The monthly returns of each portfolio corresponds to the value-weight monthly returns of the stocks: $R_{p, t}=\sum_{i=1}^{n} \omega_{i, t} * R_{i, t}$. We have three explanatory variables: Market, $H M L$ and $S M B$, as described in table 1 . The following table presents, for each portfolio, the slopes and their $t$ statistics (between brackets), the adjusted $R^{2}$ and the statistic of Durbin-Watson of the 16 time-series regressions. Using least squares and White heteroskedasticity consistent standard errors and covariance, we regressed monthly returns of the 16 portfolios according to:

$$
F F 3 F M: R_{i}-R_{f}=\alpha_{i}+\beta_{i}\left(R_{M}-R_{f}\right)+s_{i} S M B+h_{i} H M L+\epsilon_{i} .
$$

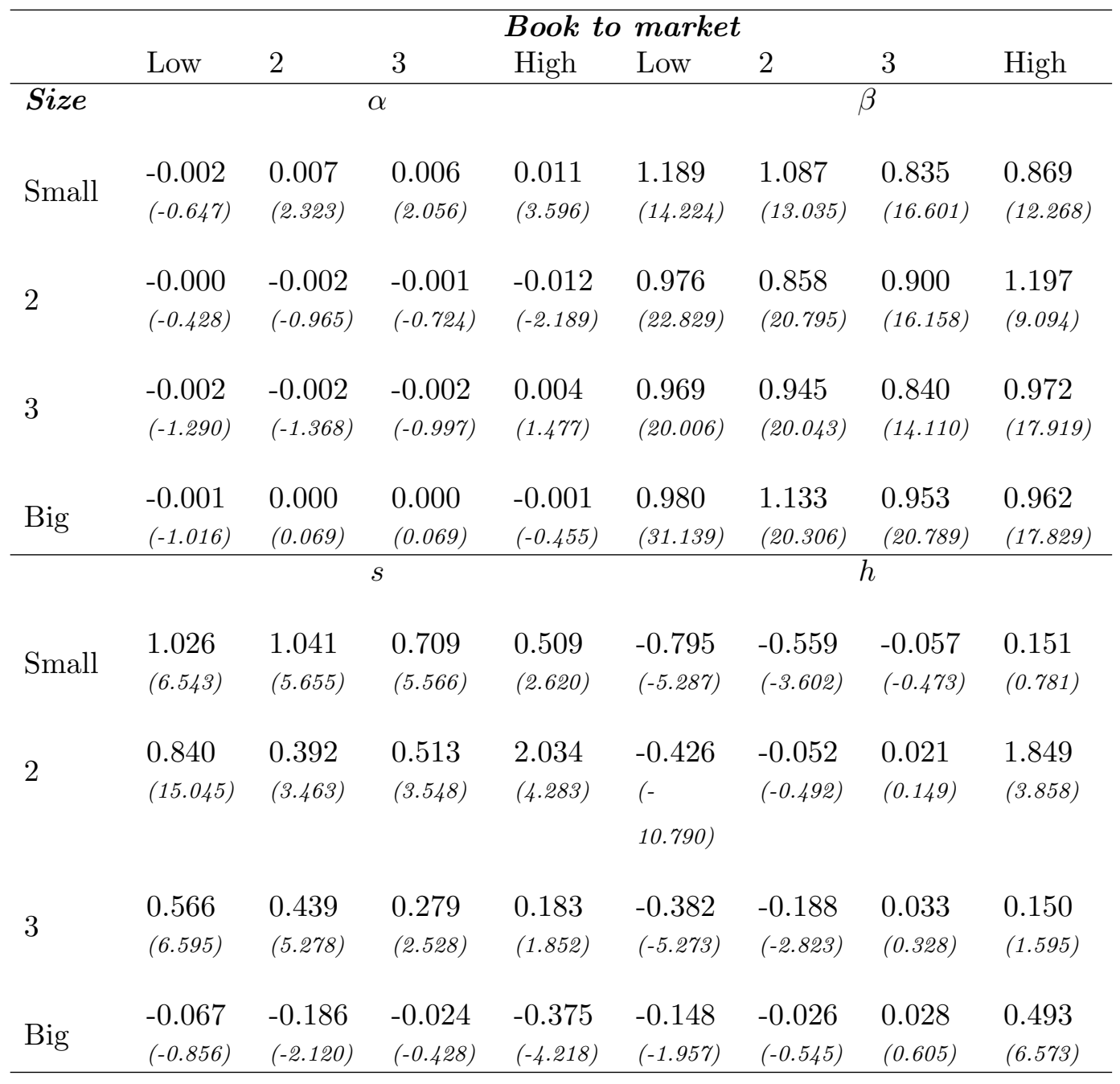


Table 4. (Continued)

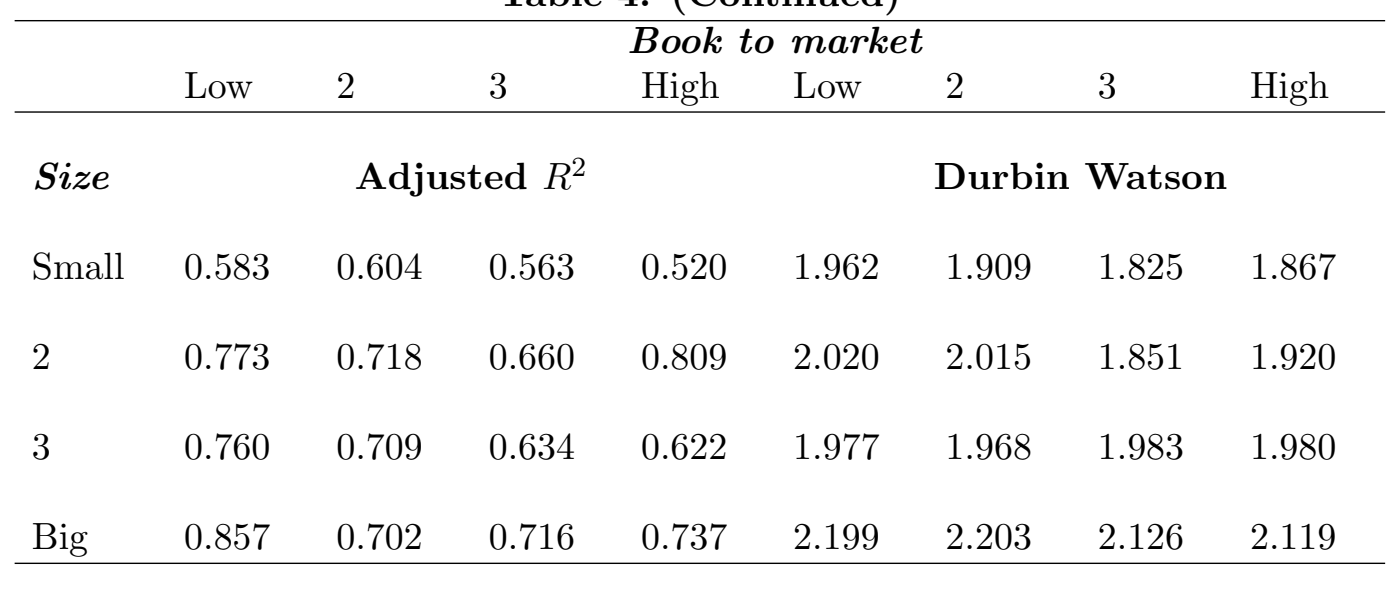

TABLE 5.

Correlation Between Market, $S M B, H M L$ and Leverage Portfolios: July 1984/June 2001 (204 months)

\begin{tabular}{lllll} 
& Mktpond. & SMB & HML & L \\
\hline Mktpond. & 1.00 & & & \\
SMB & -0.081 & 1.00 & & \\
HML & 0.051 & 0.189 & 1.00 & \\
L & 0.111 & -0.108 & 0.296 & 1.00 \\
\hline
\end{tabular}


Size And Book to Market Effects: Further Evidence

TABLE 6 .

Regressions of Monthly Excess Returns of Market, $H M L$ and $S M B$ Portfolios on Leverage Portfolio: July 1984/June 2001 (204 months)

The table presents, for each portfolio, the slopes and their $t$ statistics (between brackets), the adjusted $R^{2}$ and the statistic of Durbin-Watson of the market, $H M L$ and $S M B$ portfolios time-series regressions on leverage portfolio $(L)$. All portfolios are described in the text. Using least squares and White heteroskedasticity consistent standard errors and covariance, we regressed monthly excess returns according to:

$$
R_{i}-R_{f}=\alpha_{i}+d_{i} L+\epsilon_{i} .
$$

\begin{tabular}{|c|c|c|c|c|}
\hline & $\alpha$ & $d$ & Adjusted $R^{2}$ & $D W$ \\
\hline Mktpond. & $\begin{array}{l}0.012 \\
(2.935)\end{array}$ & $\begin{array}{l}0.253 \\
(1.170)\end{array}$ & 0.007 & 1.782 \\
\hline HML & $\begin{array}{c}0.003 \\
(0.869)\end{array}$ & $\begin{array}{l}0.732 \\
(2.145)\end{array}$ & 0.083 & 2.082 \\
\hline SMB & $\begin{array}{l}0.010 \\
(3.050)\end{array}$ & $\begin{array}{c}-0.208 \\
(-0.883)\end{array}$ & 0.006 & 1.989 \\
\hline
\end{tabular}


TABLE 7.

Regressions of Monthly Excess Returns of The 16 Portfolios on Market and Leverage Factors: From July 1984 to June 2001 (204 months)

The following table gives the slopes and their $t$ statistics (between brackets), the adjusted $R^{2}$ and the statistic of Durbin-Watson of the 16 time-series regressions. Using least squares and White heteroskedasticity consistent standard errors and covariance, we regress monthly returns of the 16 portfolios according to:

$$
R_{i}-R_{f}=\alpha_{i}+\beta_{i}\left(R_{M}-R_{f}\right)+d_{i} L+\epsilon_{i} .
$$

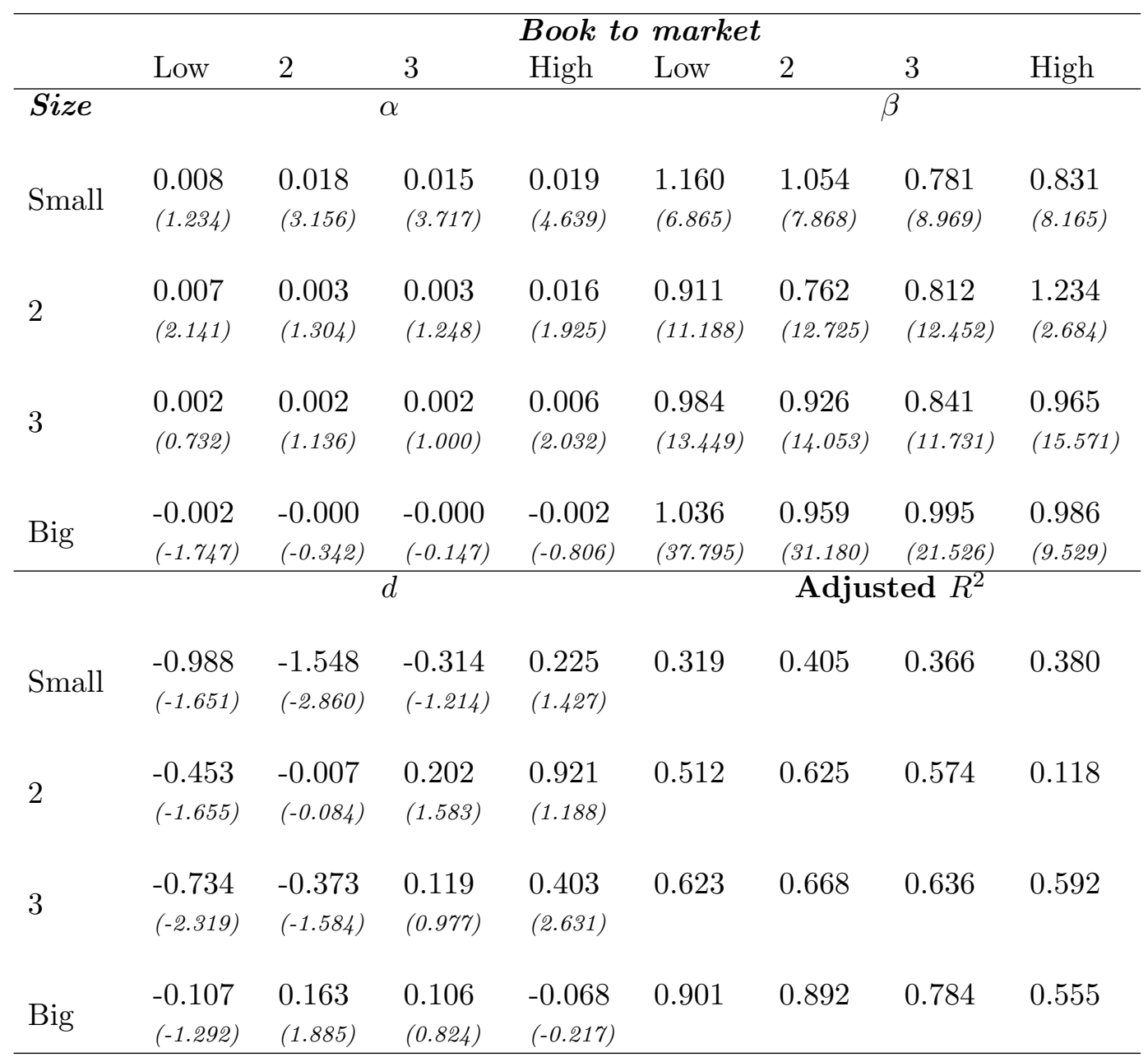


Size And Book to Market Effects: Further Evidence

Table 7. (Continued)

\begin{tabular}{lcccc}
\hline \multicolumn{5}{c}{ Book to market } \\
& Low & 2 & 3 & High \\
\hline \multirow{5}{*}{ Size } & & \multicolumn{4}{c}{ Durbin Watson } \\
Small & 2.065 & 1.694 & 1.619 & 1.928 \\
2 & 1.832 & 2.093 & 1.923 & 2.033 \\
3 & 1.907 & 1.705 & 2.149 & 2.113 \\
3 & & & & \\
Big & 1.951 & 2.115 & 2.173 & 2.227 \\
\hline
\end{tabular}


TABLE 8.

Regressions of Monthly Excess Returns of 16 Portfolios on Market, $S M B, H M L$, and Leverage Factors: From July 1984 to June 2001 (204 months)

The following table gives the slopes and their $t$ statistics (between brackets), the adjusted $R^{2}$ and the statistic of Durbin-Watson of the 16 time-series regressions. $S M B^{\perp}$ and $H M L^{\perp}$ are the portions of $S M B$ and $H M L$ portfolios orthogonal to the leverage portfolio. Using least squares and White heteroskedasticity consistent standard errors and covariance, we regress monthly returns of the 16 portfolios according to:

$$
R_{i}-R_{f}=\alpha_{i}+\beta_{i}\left(R_{M}-R_{f}\right)+d_{i} L+s_{i} S M B^{\perp}+h_{i} H M L^{\perp}+\epsilon_{i} .
$$

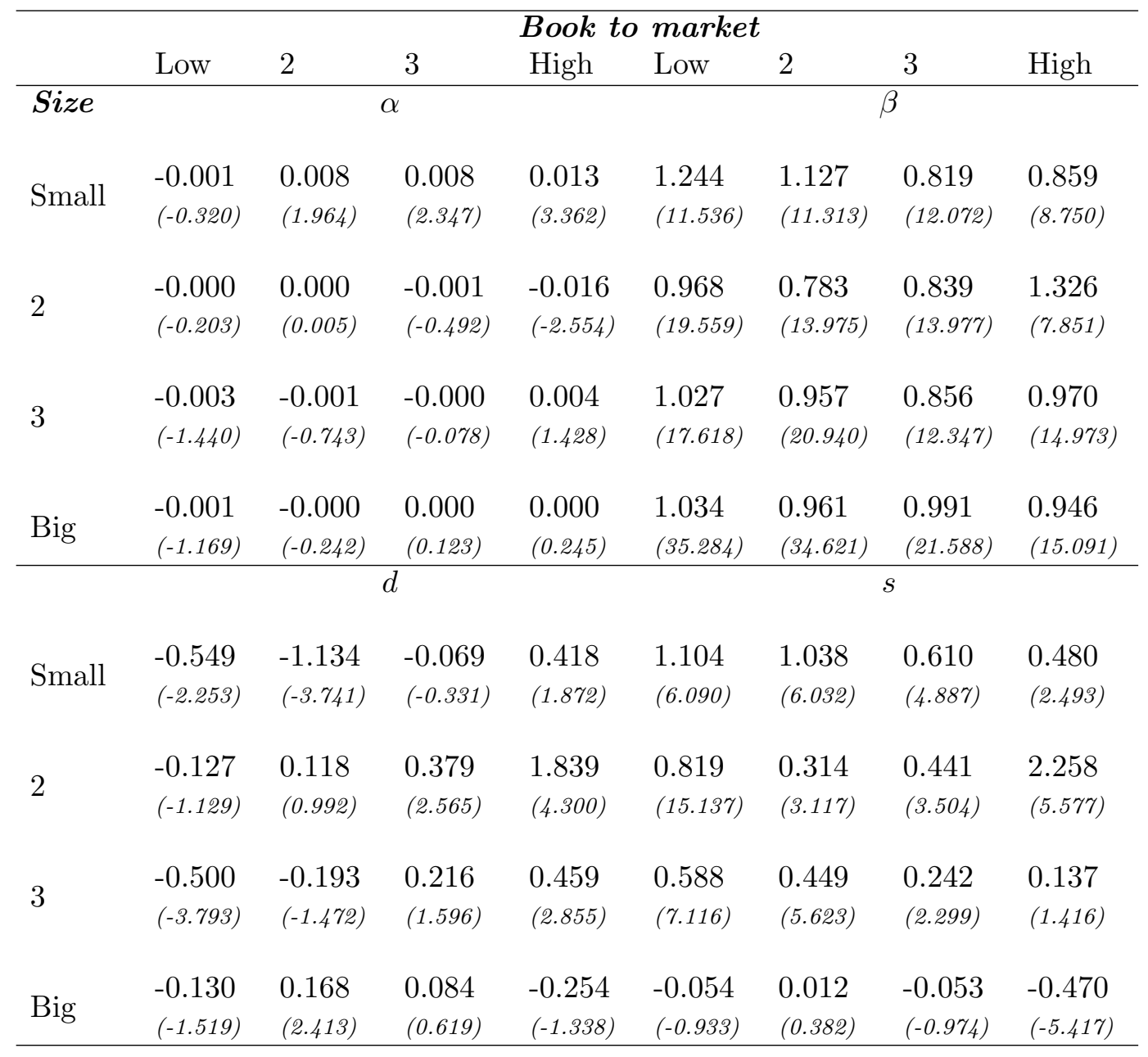


Size And Book to Market Effects: Further Evidence

TABLE 9 .

Regressions of Monthly Excess Returns of 16 Portfolios on Market, $S M B, H M L$, and Leverage Factors: From July 1984 to June 2001 (204 months)

The following table gives the slopes and their $t$ statistics (between brackets), the adjusted $R^{2}$ and the statistic of Durbin-Watson of the 16 time-series regressions. Using least squares and White heteroskedasticity consistent standard errors and covariance, we regress monthly returns of the 16 portfolios according to:

$$
R_{i}-R_{f}=\alpha_{i}+\beta_{i}\left(R_{M}-R_{f}\right)+d_{i} L^{\perp}+s_{i} S M B+h_{i} H M L+\epsilon_{i} .
$$

\begin{tabular}{|c|c|c|c|c|c|c|c|c|}
\hline & \multicolumn{8}{|c|}{ Book to market } \\
\hline & Low & 2 & 3 & High & Low & 2 & 3 & High \\
\hline Size & \multicolumn{4}{|c|}{$\alpha$} & \multicolumn{4}{|c|}{$\beta$} \\
\hline Small & $\begin{array}{l}-0.001 \\
(-0.320)\end{array}$ & $\begin{array}{l}0.008 \\
(1.964)\end{array}$ & $\begin{array}{l}0.008 \\
(2.347)\end{array}$ & $\begin{array}{l}0.013 \\
\text { (3.362) }\end{array}$ & $\begin{array}{l}1.244 \\
(11.536)\end{array}$ & $\begin{array}{l}1.127 \\
(11.313)\end{array}$ & $\begin{array}{l}0.819 \\
(12.072)\end{array}$ & $\begin{array}{l}0.859 \\
(8.750)\end{array}$ \\
\hline 2 & $\begin{array}{l}-0.000 \\
(-0.203)\end{array}$ & $\begin{array}{l}0.000 \\
(0.005)\end{array}$ & $\begin{array}{l}-0.001 \\
(-0.492)\end{array}$ & $\begin{array}{l}-0.016 \\
(-2.554)\end{array}$ & $\begin{array}{l}0.968 \\
(19.559)\end{array}$ & $\begin{array}{l}0.783 \\
(13.975)\end{array}$ & $\begin{array}{l}0.839 \\
(13.977)\end{array}$ & $\begin{array}{l}1.326 \\
(7.851)\end{array}$ \\
\hline 3 & $\begin{array}{l}-0.003 \\
(-1.440)\end{array}$ & $\begin{array}{l}-0.001 \\
(-0.743)\end{array}$ & $\begin{array}{l}-0.000 \\
(-0.078)\end{array}$ & $\begin{array}{l}0.004 \\
(1.428)\end{array}$ & $\begin{array}{l}1.027 \\
(17.618)\end{array}$ & $\begin{array}{l}0.957 \\
(20.940)\end{array}$ & $\begin{array}{l}0.856 \\
(12.347)\end{array}$ & $\begin{array}{l}0.970 \\
(14.973)\end{array}$ \\
\hline Big & $\begin{array}{c}-0.001 \\
(-1.169)\end{array}$ & $\begin{array}{l}-0.000 \\
(-0.242)\end{array}$ & $\begin{array}{l}0.000 \\
(0.123)\end{array}$ & $\begin{array}{l}0.000 \\
(0.245)\end{array}$ & $\begin{array}{l}1.034 \\
(35.284)\end{array}$ & $\begin{array}{l}0.961 \\
(34.621)\end{array}$ & $\begin{array}{l}0.991 \\
(21.588)\end{array}$ & $\begin{array}{l}0.946 \\
(15.091)\end{array}$ \\
\hline & \multicolumn{4}{|c|}{$d$} & \multicolumn{4}{|c|}{$s$} \\
\hline Small & $\begin{array}{l}-0.155 \\
(-0.554)\end{array}$ & $\begin{array}{l}-0.962 \\
(-3.425)\end{array}$ & $\begin{array}{l}-0.140 \\
(-0.651)\end{array}$ & $\begin{array}{l}0.286 \\
(1.485)\end{array}$ & $\begin{array}{l}1.118 \\
(6.447)\end{array}$ & $\begin{array}{l}1.123 \\
(6.180)\end{array}$ & $\begin{array}{l}0.623 \\
(5.023)\end{array}$ & $\begin{array}{l}0.455 \\
\text { (2.342) }\end{array}$ \\
\hline 2 & $\begin{array}{l}-0.014 \\
(-0.117)\end{array}$ & $\begin{array}{l}0.112 \\
(1.135)\end{array}$ & $\begin{array}{l}0.319 \\
\text { (2.727) }\end{array}$ & $\begin{array}{l}-0.176 \\
(-0.539)\end{array}$ & $\begin{array}{l}0.820 \\
(16.153)\end{array}$ & $\begin{array}{l}0.304 \\
\text { (2.952) }\end{array}$ & $\begin{array}{l}0.412 \\
\text { (3.212) }\end{array}$ & $\begin{array}{l}2.274 \\
(5.577)\end{array}$ \\
\hline 3 & $\begin{array}{l}-0.353 \\
(-3.105)\end{array}$ & $\begin{array}{l}-0.152 \\
(-1.297)\end{array}$ & $\begin{array}{l}0.181 \\
(1.574)\end{array}$ & $\begin{array}{l}0.344 \\
\text { (2.273) }\end{array}$ & $\begin{array}{l}0.620 \\
(7.147)\end{array}$ & $\begin{array}{l}0.462 \\
(5.447)\end{array}$ & $\begin{array}{l}0.226 \\
(2.085)\end{array}$ & $\begin{array}{l}0.106 \\
(1.101)\end{array}$ \\
\hline Big & $\begin{array}{l}-0.055 \\
(-0.780)\end{array}$ & $\begin{array}{l}0.225 \\
(3.080)\end{array}$ & $\begin{array}{l}0.092 \\
(0.629)\end{array}$ & $\begin{array}{l}-0.564 \\
(-2.658)\end{array}$ & $\begin{array}{l}-0.049 \\
(-0.815)\end{array}$ & $\begin{array}{l}-0.007 \\
(-0.218)\end{array}$ & $\begin{array}{l}-0.061 \\
(-1.169)\end{array}$ & $\begin{array}{l}-0.420 \\
(-5.202)\end{array}$ \\
\hline
\end{tabular}


TABLE 10

Cross-Sectional Regressions : July 1984/June 2001

\begin{tabular}{|c|c|c|c|c|}
\hline \multicolumn{5}{|c|}{$\begin{array}{l}\text { Panel A: Traditional CAPM } \\
R_{i, t}-R_{f, t}=\gamma_{0}+\gamma_{M k t} \hat{\beta}_{i}^{M k t}+\epsilon_{i, t}\end{array}$} \\
\hline & $\gamma_{0}$ & $\gamma_{M k t}$ & & \\
\hline Coefficient & 0.0271 & -0.0145 & & \\
\hline t-statistic & (2.735) & $(-1.656)$ & & \\
\hline \multicolumn{5}{|c|}{$R^{2}=11.12 \%$} \\
\hline \multicolumn{5}{|c|}{$\begin{array}{l}\quad \text { Panel B: Three Factor Model } \\
=\gamma_{0}+\gamma_{M k t} \hat{\beta}_{i}^{M k t}+\gamma_{S M B} \hat{\beta}_{i}^{S M B}+\gamma_{H M L} \hat{\beta}_{i}^{H M L}+\epsilon_{i, t}\end{array}$} \\
\hline \multirow{3}{*}{$\begin{array}{l}\text { Coefficient } \\
\text { t-statistic }\end{array}$} & $\gamma_{0}$ & $\gamma_{M k t}$ & $\gamma_{S M B}$ & $\gamma_{H M L}$ \\
\hline & $\begin{array}{l}0.0194 \\
(1.691)\end{array}$ & $\begin{array}{l}-0.0094 \\
(-0.827)\end{array}$ & $\begin{array}{l}0.0096 \\
(2.199)\end{array}$ & $\begin{array}{l}-0.0046 \\
(-1.184)\end{array}$ \\
\hline & & & & $R^{2}=34.22 \%$ \\
\hline
\end{tabular}

Panel C: Market and Leverage Model

\begin{tabular}{l}
$R_{i, t}-R_{f, t}=\gamma_{0}+\gamma_{M k t} \hat{\beta}_{i}^{M k t}+\gamma_{L} \hat{\beta}_{i}^{L}+\epsilon_{i, t}$ \\
\hline$\gamma_{0} \quad \gamma_{M k t} \quad \gamma_{L}$
\end{tabular}

Coefficient $\quad 0.0201 \quad-0.0073 \quad-0.0032$

t-statistic (1.897) $\quad(-0.717) \quad(-1.133)$

$$
R^{2}=20.05 \%
$$

Panel D: Three Factor Model with marginal contribution of Leverage Factor

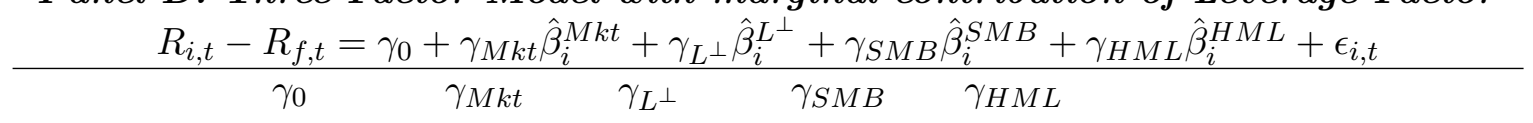

$\begin{array}{llllll}\text { Coefficient } & 0.0155 & -0.0054 & 0.0016 & 0.0092 & -0.0044\end{array}$

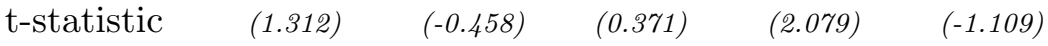

$$
R^{2}=40.25 \%
$$

Panel E: Market and Leverage with marginal contribution of $S M B$ and $H M L$

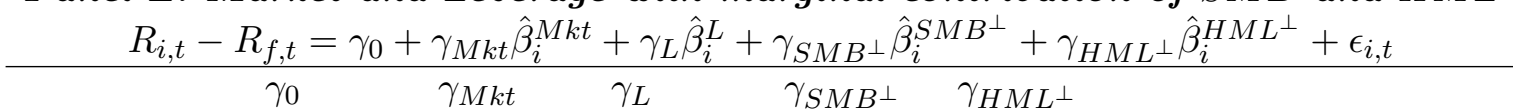

Coefficient $\quad 0.0155 \quad-0.0054 \quad 0.0002 \quad 0.0092 \quad-0.0045$

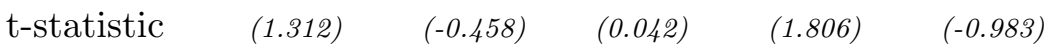

$$
R^{2}=40.25 \%
$$


Size And Book to Market Effects: Further Evidence

FIGURE 1.

Plots of Fitted versus Actual Returns of 16 Portfolios

July1984/June2001

\section{Panel A: Traditional CAPM}

$$
R_{i, t}-R_{f, t}=\gamma_{0}+\gamma_{M k t} \hat{\beta}_{i}^{M k t}+\epsilon_{i, t}
$$

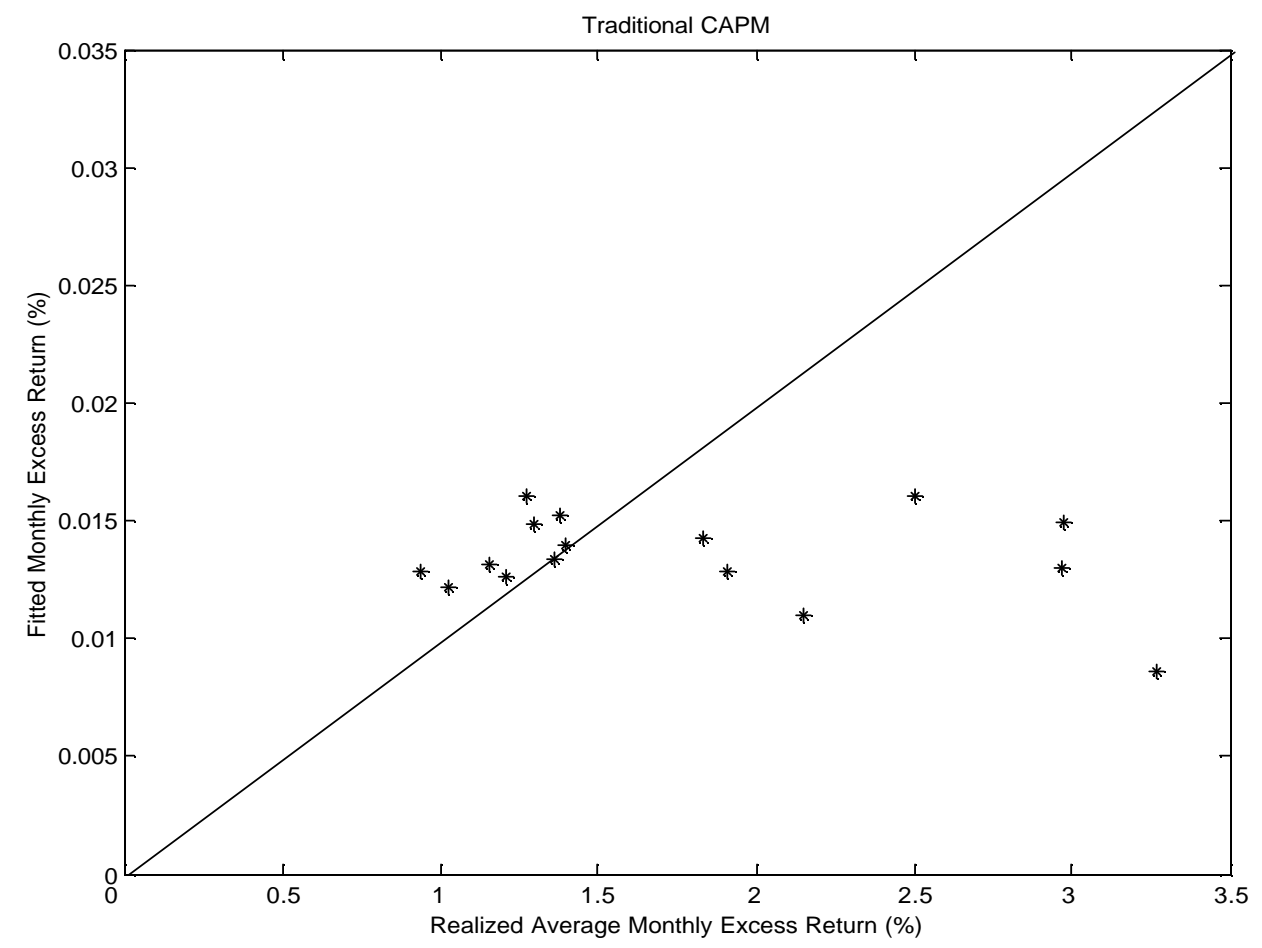


Figure 2.

Plots of Fitted versus Actual Returns of 16 Portfolios

July1984/June2001

Panel B: Three Factor Model

$R_{i, t}-R_{f, t}=\gamma_{0}+\gamma_{M k t} \hat{\beta}_{i}^{M k t}+\gamma_{S M B} \hat{\beta}_{i}^{S M B}+\gamma_{H M L} \hat{\beta}_{i}^{H M L}+\epsilon_{i, t}$

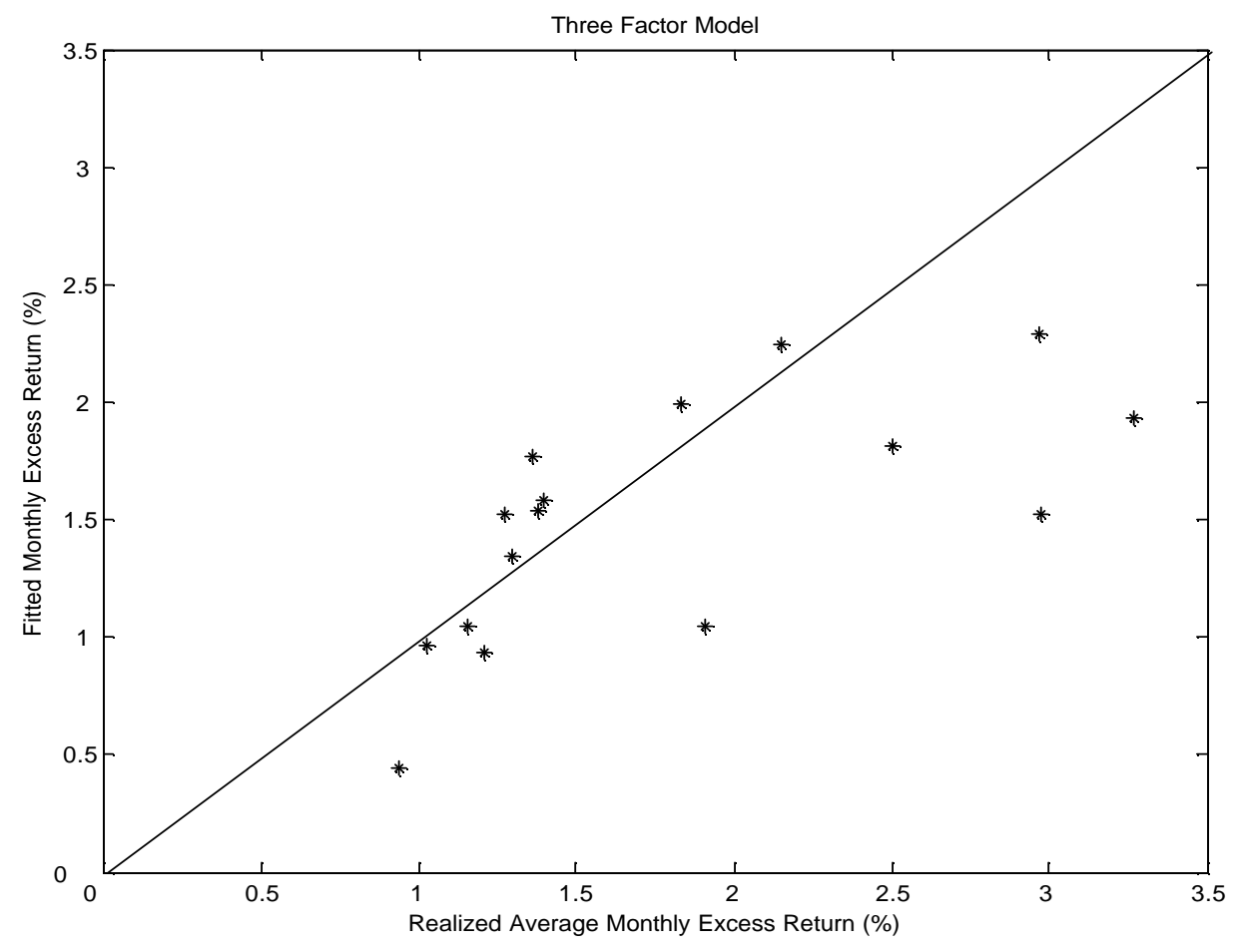


Size And Book to Market Effects: Further Evidence

Figure 3.

Plots of Fitted versus Actual Returns of 16 Portfolios

July1984/June2001

Panel C: Market and Leverage Model

$$
R_{i, t}-R_{f, t}=\gamma_{0}+\gamma_{M k t} \hat{\beta}_{i}^{M k t}+\gamma_{L} \hat{\beta}_{i}^{L}+\epsilon_{i, t}
$$

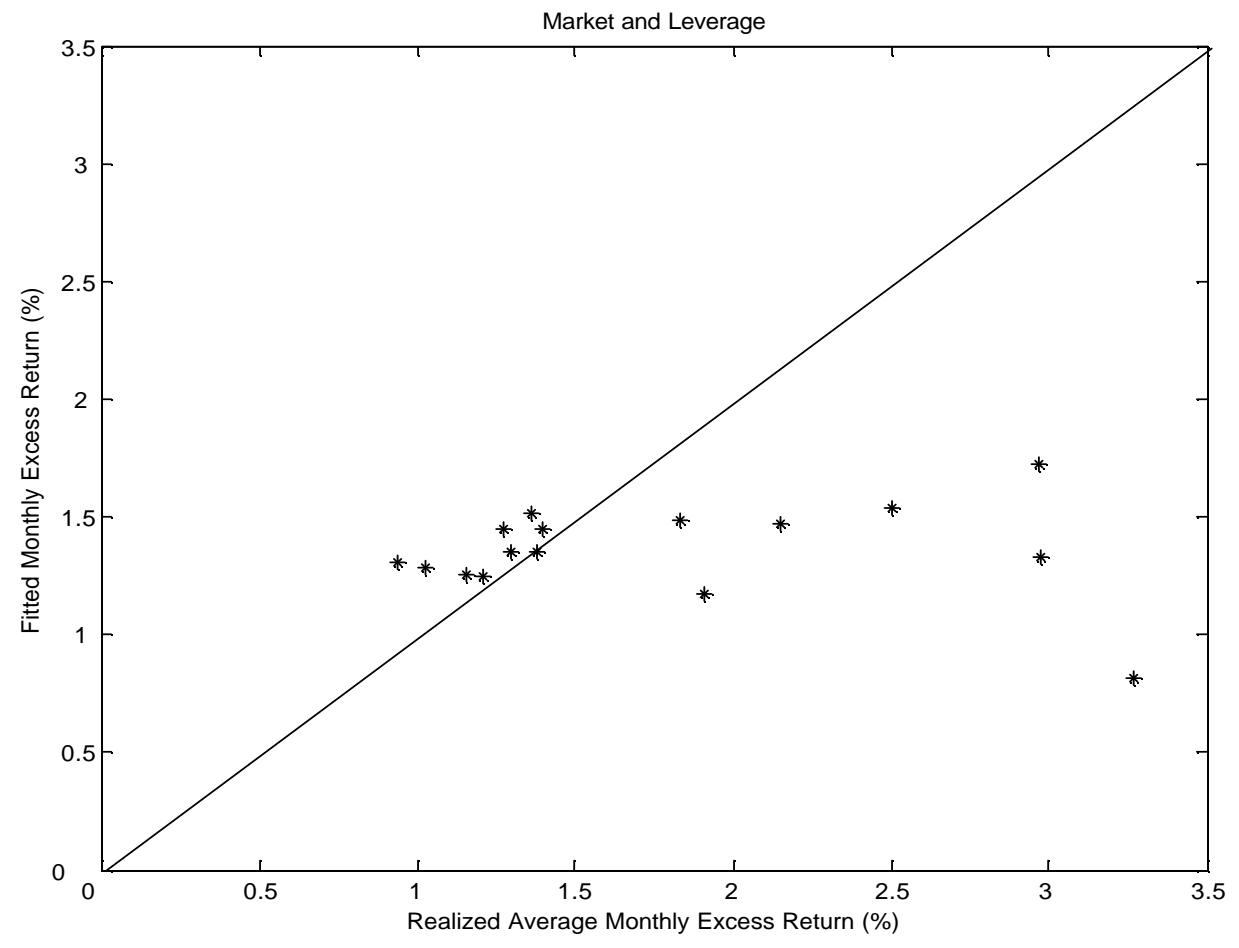


Figure 4.

Plots of Fitted versus Actual Returns of 16 Portfolios

July1984/June2001

Panel D: Three Factor Model with marginal contribution of Leverage Factor

$$
R_{i, t}-R_{f, t}=\gamma_{0}+\gamma_{M k t} \hat{\beta}_{i}^{M k t}+\gamma_{L^{\perp}} \hat{\beta}_{i}^{L^{\perp}}+\gamma_{S M B} \hat{\beta}_{i}^{S M B}+\gamma_{H M L} \hat{\beta}_{i}^{H M L}+\epsilon_{i, t}
$$

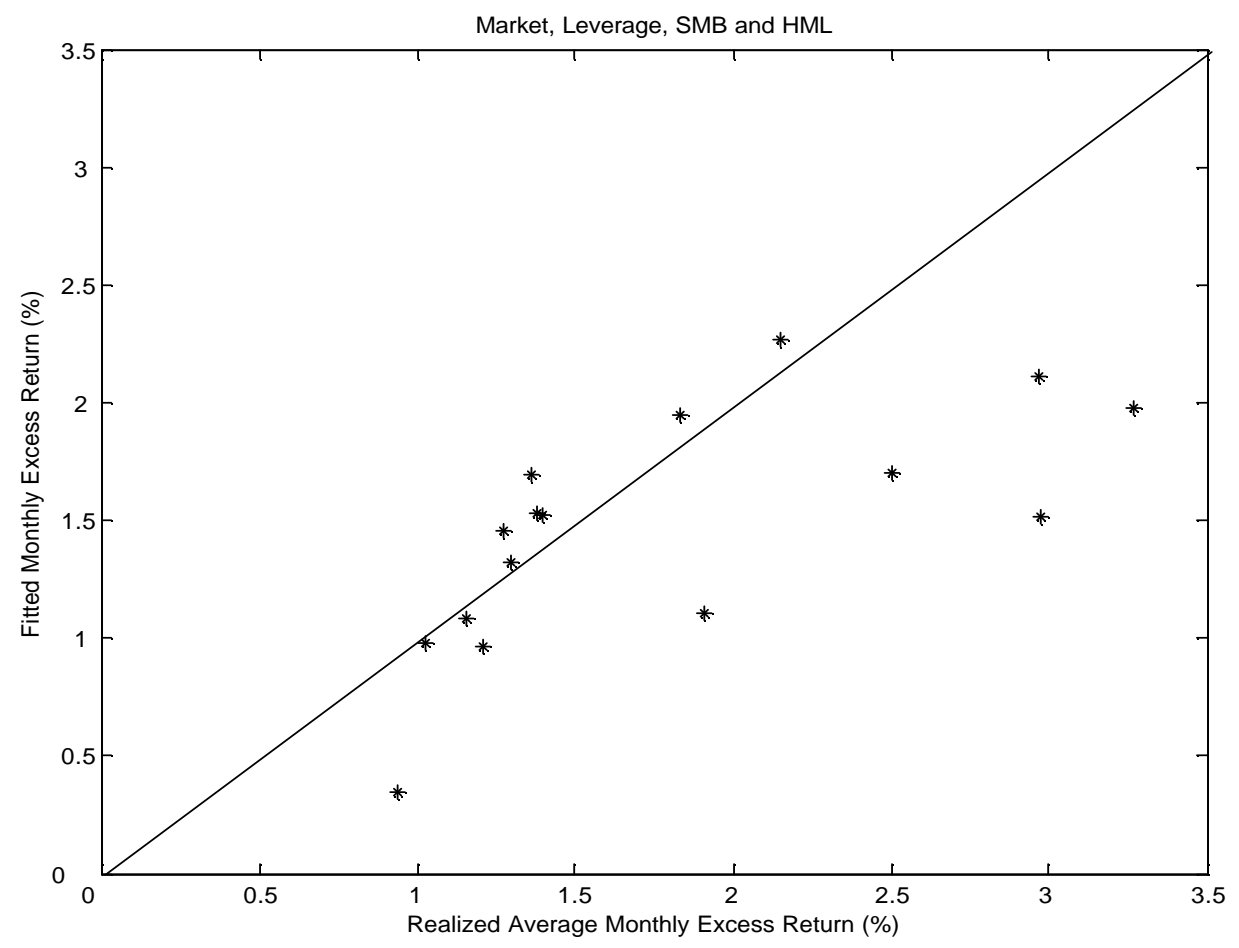


Size And Book to Market Effects: Further Evidence

FiguRE 5.

Plots of Fitted versus Actual Returns of 16 Portfolios

July1984/June2001

Panel E: Market and Leverage with marginal contribution of $S M B$ and $H M L$

$$
R_{i, t}-R_{f, t}=\gamma_{0}+\gamma_{M k t} \hat{\beta}_{i}^{M k t}+\gamma_{L} \hat{\beta}_{i}^{L}+\gamma_{S M B^{\perp}} \hat{\beta}_{i}^{S M B^{\perp}}+\gamma_{H M L^{\perp}} \hat{\beta}_{i}^{H M L^{\perp}}+\epsilon_{i, t}
$$

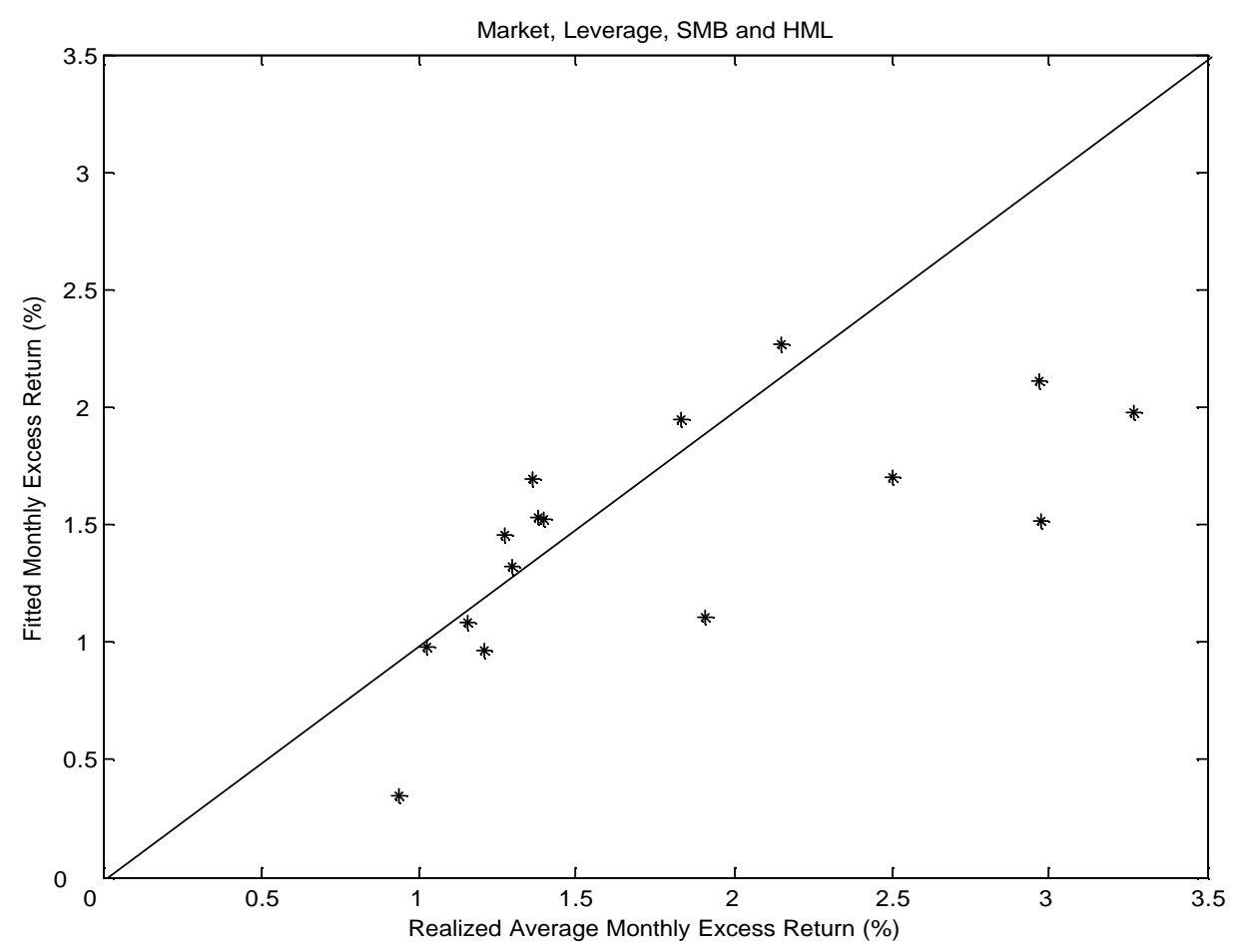

